\title{
MODELING OF COUPLED HEAT TRANSFER AND REACTIVE TRANSPORT PROCESSES IN POROUS MEDIA: APPLICATION TO SEEPAGE STUDIES AT YUCCA MOUNTAIN, NEVADA
}

\author{
Sumit Mukhopadhyay*, Eric L. Sonnenthal, and Nicolas Spycher \\ Lawrence Berkeley National Laboratory, Berkeley, California, 94720, USA
}

\begin{abstract}
When hot radioactive waste is placed in subsurface tunnels, a series of complex changes occurs in the surrounding medium. The water in the pore space of the medium undergoes vaporization and boiling. Subsequently, vapor migrates out of the matrix pore space, moving away from the tunnel through the permeable fracture network. This migration is propelled by buoyancy, by the increased vapor pressure caused by heating and boiling, and through local convection. In cooler regions, the vapor condenses on fracture walls, where it drains through the fracture network. Slow imbibition of water thereafter leads to gradual rewetting of the rock matrix. These thermal and hydrological processes also bring about chemical changes in the medium. Amorphous silica precipitates from boiling and evaporation, and calcite from heating and $\mathrm{CO}_{2}$ volatilization. The precipitation of amorphous silica, and to a much lesser extent calcite, results in long-term permeability reduction. Evaporative concentration also results in the precipitation of gypsum (or anhydrite), halite, fluorite and other salts. These evaporative minerals eventually redissolve after the boiling period is over, however, their precipitation results in a significant temporary decrease in permeability. Reduction of permeability is also associated with changes in fracture capillary characteristics. In short, the coupled thermal-hydrological-chemical (THC) processes dynamically alter the hydrological properties of the rock. A model based on the TOUGHREACT reactive transport software is presented here to investigate the impact of THC processes on flow near an emplacement tunnel at Yucca Mountain, Nevada. We show how transient changes in hydrological properties caused by THC processes often lead to local flow channeling and saturation increases above the tunnel. For models that include only permeability changes to fractures, such local flow channeling may lead to seepage relative to models where THC effects are ignored. However, coupled THC seepage models that include both permeability and capillary changes to fractures may not show this additional seepage.
\end{abstract}

\footnotetext{
*Corresponding author: Smukhopadhyay@lbl.gov
} 


\section{Intorduction}

Emplacement of hot, radioactive waste in underground tunnels is expected to set off various coupled thermal-hydrological-chemical (THC) processes in the unsaturated fractured rock of Yucca Mountain, Nevada. Focusing first on coupled thermal-hydrological (TH) processes (Figure 1), we expect the heat emanating from the radioactive waste to cause vaporization and boiling of the matrix pore water, with subsequent migration of vapor out of the matrix into the embedded fractures. Once in the fracture, water vapor will move away from the tunnel through the permeable fracture network by buoyancy, by the increased vapor pressure resulting from heating and boiling, and by local convection. In cooler regions, vapor will condense on fracture walls, where it will flow through the fracture network under gravity drainage or will be absorbed back into the matrix (because of the stronger capillarity of the matrix pores). Slow imbibition of water from fractures into the matrix gradually leads to increases in the liquid saturation of the rock matrix.

Under conditions of continuous thermal loading, a dryout zone will eventually develop closest to the heat source, separated from the condensation zone by a nearly isothermal zone maintained at about boiling temperature of water. This nearly isothermal zone is characterized by a continuous process of boiling, vapor transport, condensation, and migration of water back to the heat source (either by capillary forces or gravity drainage), often called a heat pipe (Pruess et al., 1990). TH processes in the unsaturated fractured rocks of Yucca Mountain have been extensively examined since the early 1980s (Pruess et al., 1984; Pruess et al., 1990; Buscheck and Nitao, 1993; Pruess, 1997; Kneafsy and Pruess, 1998; Haukwa et al., 1999; Buscheck et al., 2002; Haukwa et al., 2003; Birkholzer et al., 2004;

Birkholzer et al., 2005; Wu et al., 2006). The methodology used in these predictive studies have also been validated against the TH response of large in situ heater tests conducted at the repository site (Tsang and Birkholzer, 1999; Birkholzer and Tsang, 2000; Mukhopadhyay and Tsang, 2002; Mukhopadhyay and Tsang, 2003; Birkholzer et al., 2005).

Simultaneous to the $\mathrm{TH}$ processes, the unsaturated fractured rock also undergoes substantial chemical changes. The chemical evolution of waters, gases, and minerals is intimately coupled to the TH processes (boiling, condensation, and drainage) discussed above. Distribution of condensate in the fracture system 


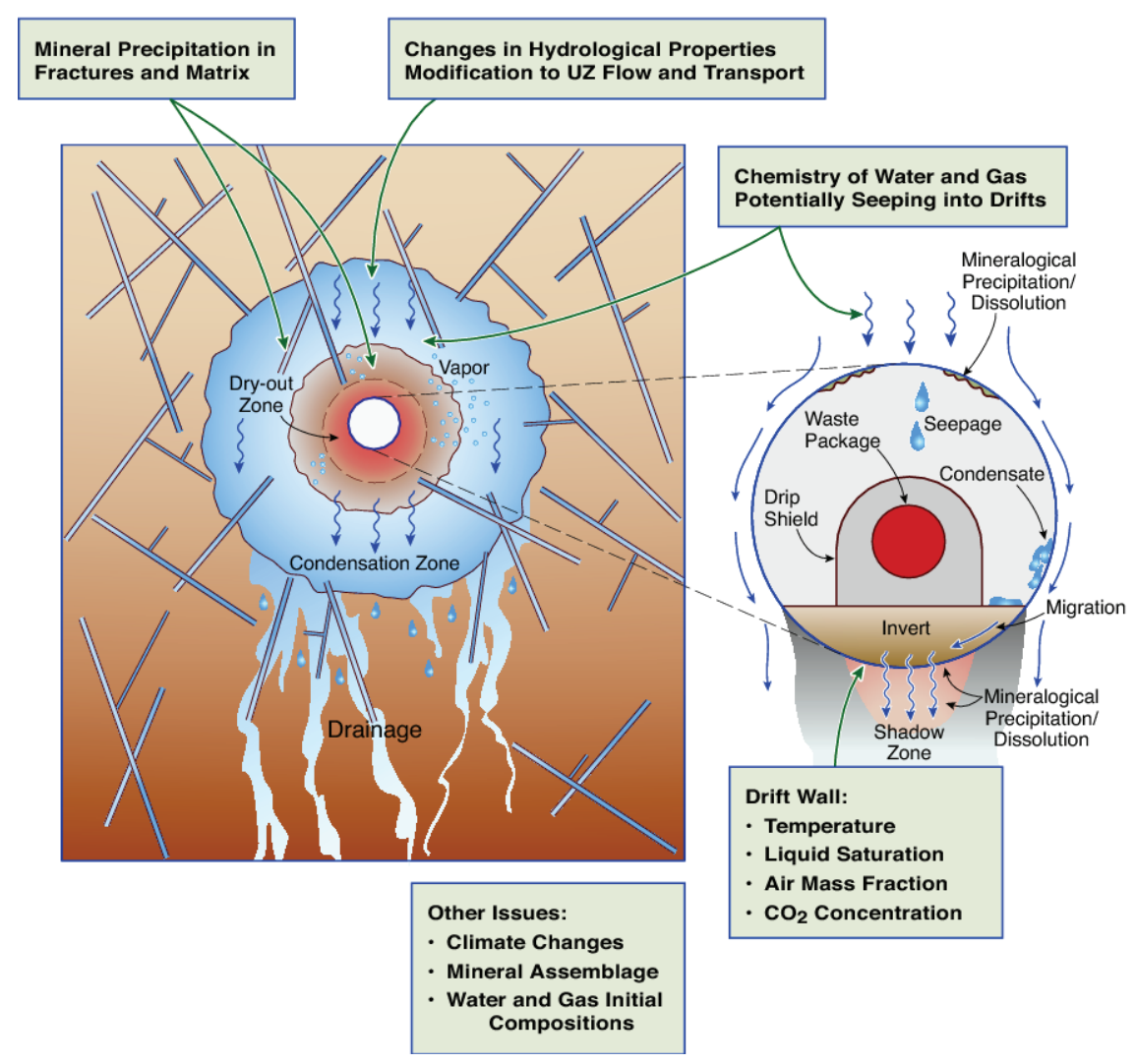

Figure 1. Schematic representation of interaction of TH and geochemical processes in the fractured rock of Yucca Mountain

determines where mineral dissolution and precipitation can occur in the fractures and where there can be direct interaction (via diffusion) between matrix pore waters and fracture waters. Figure 1 schematically shows the relationships between TH and chemical processes in the zones of boiling, condensation, and drainage, in the rock mass at the fracture-matrix interface surrounding an emplacement tunnel.

In short, redistribution of mineral phases will occur as a result of differences in mineral solubility as a function of temperature. The inverse relation between temperature and calcite solubility (as opposed to the silica phases, which are more soluble at higher temperatures) will also cause zonation in the distribution of calcite and silica phases in both the condensation and boiling zones (Figure 1). Precipitation of amorphous silica or another silica phase is likely to be confined to a narrower zone, where the evaporative concentration from boiling exceeds its solubility. In contrast, calcite could precipitate in fractures over a broad zone of elevated temperature and where $\mathrm{CO}_{2}$ has exsolved because of temperature increases or boiling. Alteration of feldspars to clays and zeolites is likely to be most rapid in the boiling zone because of their increased solubility (as well as higher dissolution and precipitation fluxes) at higher temperatures (Lasaga, 1998). 
Coupled THC processes in the unsaturated fractured rock of Yucca Mountain have been under thorough investigation for some time now (Sonnenthal et al., 2001; Xu and Priess, 2001; Sonnenthal et al., 2003; Spycher et al., 2003; Sonnenthal and Spycher, 2004; Spycher et al., 2004; Sonnenthal et al., 2005; Spycher et al., 2005a, Spycher et al., 2005b). These THC modeling studies investigate the coupling among heat, water, and vapor flow, aqueous and gaseous species transport, kinetic and equilibrium mineral-water reactions, and feedback of mineral precipitation/dissolution on porosity, permeability, and capillary pressure. Such studies also develop the underlying conceptual and mathematical models, which provide the basis for modeling the $\mathrm{TH}$ effects of the relevant mineral-water-gas reactions and transport processes in the host rock.

While the overall impact of THC processes in unsaturated fractured rock has been dealt with in those previous investigations, this paper focuses on one particular aspect - the changes in the hydrologic properties of the unsaturated fractured rock, caused by the THC processes. THC processes of mineral precipitation and dissolution dynamically change the hydraulic properties of the rock (such as porosity, permeability, and capillary characteristics). These changes, in turn, cause perturbations in the flow fields around an emplacement tunnel, which may lead to local flow channeling. In this paper we show that simulations may predict seepage (i.e., dripping of liquid water from the unsaturated rock into the emplacement tunnels) because of such local flow channeling, depending on how changes in capillary response are represented. The objective of this paper is thus to investigate the impact of THC processes on seepage.

Understanding the processes affecting seepage is important, because seepage (or its absence) is directly connected to the overall performance of a repository in successfully isolating nuclear waste from the geosphere. For example, if seepage occurs, it may promote corrosion of the waste packages, which may lead to release of radioactive materials from the emplacement tunnels into the surrounding rock. Both experimental and modeling analyses (Wang et al., 1999; Trautz and Wang, 2002; Finsterle et al., 2003; Ghezzehei et al., 2004) have been performed to determine the processes affecting seepage under ambient conditions, i.e., in the absence of any thermal effects. Predictive modeling studies, based on a stochastic continuum model, have also been carried out to predict the probability and magnitude of seepage under ambient conditions at Yucca Mountain (Li and Tsang, 2003; Tsang et al., 2004). 
These previous studies have generally concluded that seepage under ambient conditions is reduced or prevented by the "capillary barrier" effect (i.e., the difference in capillary pressure between the rock formation and a large underground opening such as the emplacement tunnel). This capillary barrier effect causes water to be mostly diverted around the tunnels rather than seeping into them. However, according to those earlier investigations, seepage under ambient conditions can still occur when local flow channeling, caused by heterogeneities in the host rock, results in local saturation buildup. If the saturation buildup exceeds a certain threshold saturation (see below for further discussion), the capillary barrier is overcome, and seepage commences. Thus, heterogeneity plays a crucial role in controlling seepage.

Since the emplaced waste imposes considerable thermal load on the surrounding rock, seepage under thermal conditions has also been investigated at Yucca Mountain through development of TH seepage models (Birkholzer et al., 2004; Birkholzer et al., 2005). While the capillary barrier effect and heterogeneity of the host rock were found to control seepage even under thermal conditions (similar to ambient seepage), some significant differences in the mechanism of seepage between the two were also observed. The superheated dryout zone outside the emplacement tunnel under thermal conditions subjected incoming water to vigorous boiling, preventing liquid water from reaching the tunnel (i.e., liquid water could reach the tunnel wall only after the dryout zone had disappeared). In other words, the dryout zone provides an additional barrier to seepage, effectively creating what has been termed a "vaporization barrier" (Birkholzer et al., 2004; Birkholzer et al., 2005). Because of this, seepage under thermal conditions in general commences later than ambient seepage, and the quantity of seepage under thermal conditions is smaller than ambient seepage (Birkholzer et al., 2004; Birkholzer et al., 2005).

While the analyses in (Birkholzer et al., 2004; Birkholzer et al., 2005) provide an important framework for investigating seepage including TH effects, the THC changes in the host rock are not included in their conceptual model. It has only recently been shown (Spycher et al., 2005b; Mukhopadhyay et al., 2006) that the THC conditions in the rock are pertinent for seepage, not only for the chemistry of the seepage water but also for the amount and duration of seepage. As stated earlier, heterogeneity in the host rock plays a key role in controlling seepage. By changing the hydrologic properties of the rock, the THC processes introduce further heterogeneities in the rock. Thus, the transient pattern of seepage under THC is different from that when only ambient or TH processes are considered. 
The feedback of the THC processes on the hydrologic properties of the rock has been shown (Spycher et al., 2005b; Mukhopadhyay et al., 2006) to cause alteration of the flow pattern near the emplacement tunnels, resulting in seepage under some circumstances (Spycher et al., 2005b; Mukhopadhyay et al., 2006). However, the analyses in (Spycher et al., 2005b; Mukhopadhyay et al., 2006) were performed assuming dynamic changes in permeability and porosity only, i.e., the feedback of THC processes was restricted to only those two hydrologic properties. In reality, however, mineral precipitation and dissolution also alter the capillary characteristics of the rock, which have a direct impact on flow channeling and seepage. In this paper, we perform simulations in the unsaturated fractured rock of Yucca Mountain to analyze the feedback of THC processes on the hydrologic properties (porosity, permeability, and capillarity) of the rock and ultimately on seepage. We also perform ambient and TH simulations to illustrate the difference between these processes in the context of seepage (or its absence).

\section{Seepage and THC Processes}

When liquid water, having flowed through the unsaturated rock, reaches the immediate vicinity of an emplacement tunnel, a layer of increased saturation is expected to develop as a result of the capillary barrier effect from the tunnel opening (Philip et al., 1989; Finsterle, 2000; Jackson et al., 2000; Finsterle et al., 2003). Water is prevented from seeping into the tunnel because of capillary suction, which retains the wetting fluid in the pore space of the rock. This barrier effect leads to a local saturation build-up in the rock next to the interface between the geologic formation and the tunnel. If the permeability (as well as the capillarity) of the fracture network within this layer is sufficiently high, all or a portion of the water is diverted around the tunnel under partially saturated conditions. Locally, however, the water potential in the formation may be higher than that in the tunnel, and then water exits the formation and enters the tunnels, resulting in seepage.

In the unsaturated fractured rock of Yucca Mountain, the fractures form a well-connected network. As a result, flow is mostly carried in the fractures. Moreover, because the permeability of the rock matrix is a few orders of magnitude smaller than that of the fracture, flow in the rock matrix is considerably slower. In addition, the small porosities of the rock matrix ensure a stronger capillary suction compared to the fractures. Thus, the matrix mainly provides storage, while flow takes place through the fractures. Seepage from the matrix is thus expected to be significantly smaller than those from the fractures. The formulation that follows is therefore focused on the flow in fractures. 
Earlier studies (Finsterle, 2000; Jackson et al., 2000; Or and Ghezzehei, 2000; Finsterle et al., 2003; Finsterle et al., 2004) have shown that a heterogeneous porous continuum representation can be consistently used to analyze flow in unsaturated fractured rock, particularly if the fractures are roughwalled or are partially filled. For analyzing the impact of THC processes on seepage, the same fundamental approach is adopted in this paper. As an example, the mechanism of seepage into an emplacement tunnel is schematically shown in Figure 2. In that figure, flow is shown to be channeled onto a small block of rock situated above a large underground cavity. Assuming single-phase, incompressible, isothermal flow conditions, the conservation of mass in any particular discrete rock block " $i$ " can be written as

$$
V_{i} \frac{\partial}{\partial t}\left(\varphi_{i} S_{i}^{l}\right)=\sum A_{i j} q_{i j}
$$

where $\sum A_{i j} q_{i j}$ represents the net flow of water into block $i$. When this quantity is larger than zero, the liquid saturation in that particular block $\left(S_{i}^{l}\right)$ increases, and the capillary suction of the rock formation decreases. This process continues until a threshold liquid saturation, $S_{i}^{l t}$, is reached, when the capillary suction of the rock formation is so weak that it cannot hold the water any more, and liquid water is allowed to seep into the drift. Once seepage begins to occur, the mass-balance equation needs to be rewritten as

$$
V_{i} \frac{\partial}{\partial t}\left(\varphi_{i} S_{i}^{l}\right)=\sum A_{i j} q_{i j}-A_{s} q_{s}
$$

where $q_{s}$ is the rate of seepage and $A_{s}$ is the area of contact between the rock block and the cavity. The rate of seepage can be further written as $q_{s}=-\frac{k_{s}}{\mu h}\left(P_{C}-\rho g h\right)$

where $k_{s}$ is the permeability of the vertical connection between the rock block and cavity underneath it, and $h$ is the vertical distance between the center of the rock block and the surface of the cavity. Implicit in the above equation is the fact that seepage can occur only when (Finsterle et al., 2003; Birkholzer et al., 2004) 


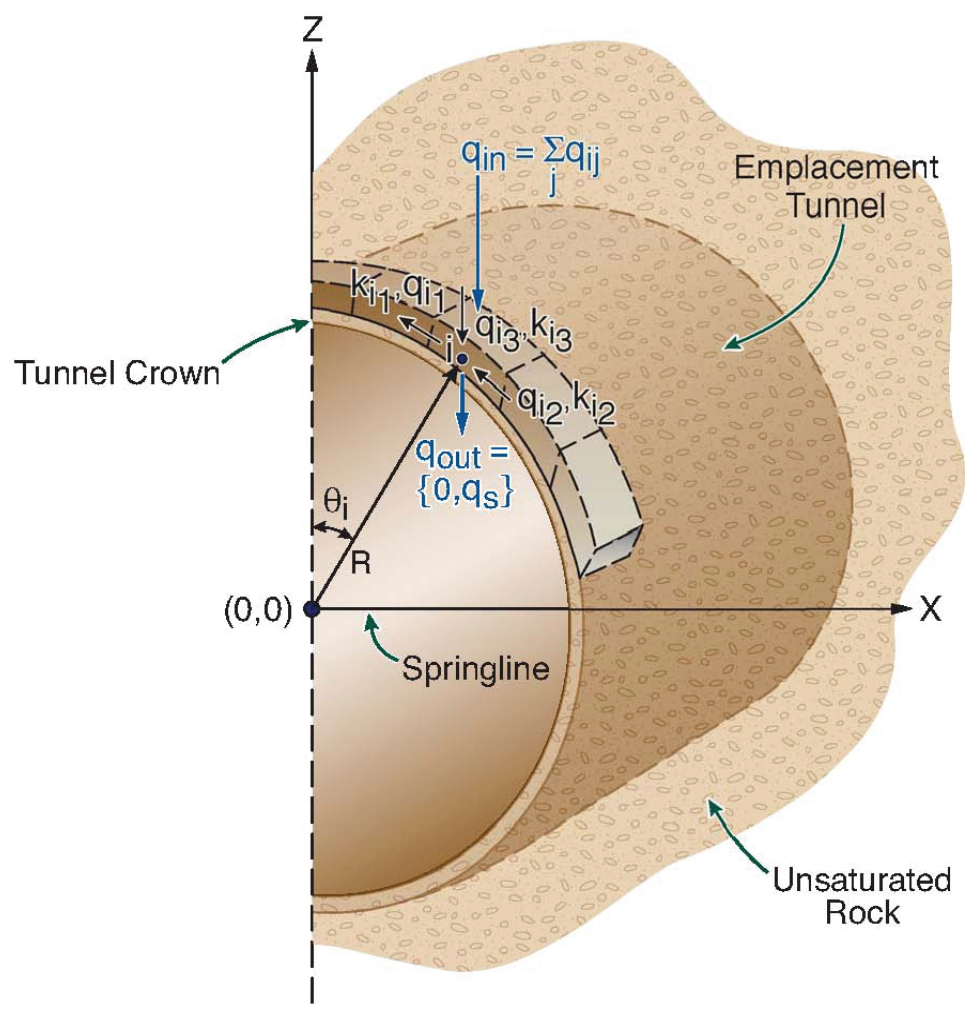

Figure 2. Schematic representation of seepage into an emplacement tunnel situated in unsaturated fractured rock

$$
P_{C} \leq \rho g h,
$$

i.e., when the capillary forces of the rock is smaller than the gravity forces pulling the water into the cavity. Note that once seepage begins to occur, it will continue as long as the net flow of water into the rock block $i$ is larger than the seepage flux out of it (Equation 2), i.e.,

$$
\sum A_{i j} q_{i j} \geq \frac{k_{s}}{\mu h}\left|P_{C}-\rho g h\right|, P_{C} \leq \rho g h .
$$

On the other hand, if the above condition is not satisfied (i.e., if the net flow of water into the block is less than the seepage flux), the saturation in rock block $i$ will decrease (and fall below the threshold saturation over time), the capillary suction of the rock will increase, and seepage will stop. 
It has already been shown (Equation 4) that seepage can take place only when the capillary suction of the fractures is smaller than the gravitational forces. Since the capillary pressure is a function of liquid saturation, Equation 4 can be rewritten as

$$
\frac{1}{\alpha_{i}} F\left(S_{i}^{l}\right) \leq \rho g h
$$

where $\left(1 / \alpha_{i}\right)$ is the fracture capillary strength parameter of block $i$ and $\left(1 / \alpha_{i}\right) F\left(S_{i}^{l}\right)$ represents the dependence of fracture capillary pressure on liquid saturation $\left(S_{i}^{l}\right)$. It is also known that the fracture $\left(1 / \alpha_{i}\right)$ parameter changes with fracture porosity $\left(\phi_{i}\right)$ and permeability $\left(k_{i}\right)$ of block $i$ through Leverett scaling (Leverett, 1941) as

$$
\frac{1}{\alpha_{i}}=\frac{1}{\alpha_{0}} \sqrt{\frac{k_{0}}{k_{i}} \frac{\varphi_{i}}{\varphi_{0}}}
$$

where $\left(1 / \alpha_{0}\right)$ is the ambient (or pre-heating) value of the fracture $(1 / \alpha)$ parameter, assumed homogeneous, and $\varphi_{0}$ and $k_{0}$ are the mean fracture porosity and permeability, respectively. Thus, a seepage threshold saturation, $S_{i}^{l t}$, can be defined such that

$$
F\left(S_{i}^{l t}\right)=\left[\alpha_{0} \rho g h \sqrt{\frac{k_{i}}{k_{0}} \frac{\varphi_{0}}{\varphi_{i}}}\right] .
$$

In other words, seepage will happen only when the fracture saturation is larger than or equal to $S_{i}^{l t}$. According to the van Genuchten (van Genuchten, 1980) relations and the formulations of the active fracture model (Liu et al., 1998), $F\left(S_{i}^{l}\right)$ can be written as

$$
F\left(S_{i}^{l}\right)=\left[\left(S_{i}^{l, e}\right)^{-1 / m}-1\right]^{1-m}, S_{i}^{l, e}=\left[\frac{S_{i}^{l}-S_{i}^{l r}}{1-S_{i}^{l r}}\right]^{1-\gamma}
$$


where $m$ and $\gamma$ are the van Genuchten' exponent (van Genuchten, 1980) and active fracture parameters (Liu et al., 1998), respectively, and $S_{i}^{l r}$ is the irreducible fracture saturation. Combining Equations 8 and 9 , it can be further written that

$$
S_{i}^{l t}=S_{i}^{l r}+\left(1-S_{i}^{l r}\right)\left[1+\left\{\alpha \rho g h \sqrt{\frac{k_{i}}{k_{0}} \frac{\varphi_{0}}{\varphi_{i}}}\right\}^{\frac{1}{1-m}}\right]^{-\frac{m}{1-\gamma}}
$$

It is now easy to understand the impact of THC processes (specifically mineral precipitation and dissolution) on seepage. Observe that the seepage threshold saturations (Equation 10) are different when THC processes are accounted for than when they are not. To understand this more clearly, let us assume that all the fractures have the same capillarity, i.e., let us ignore Leverett scaling (Leverett, 1941) as depicted in Equation 7. In this instance, fractures with a relatively large deposition of minerals will have smaller porosities and permeabilities, and will tend to carry less flow (because of the relatively large reduction in permeabilities within these fractures). As a result, flow is diverted into fractures with relatively larger permeabilities (i.e, with less deposition), causing local flow channeling. Because of this local flow channeling, saturation in fractures with relatively larger permeabilities builds up quickly compared to other neighboring fractures and may even exceed the threshold saturation (Equation 10). This buildup of saturation in certain fractures caused by flow channeling leads to conditions favorable for seepage. Compare this situation with ambient or TH-only models. In ambient and TH-only models, where the dynamic changes in hydrologic properties because of chemical changes are not accounted for, local flow channeling is expected to be less compared to THC models.

Let us now focus on the impact of dynamic changes in capillarity arising out of changes in fracture porosity and permeability. When Leverett scaling is included, i.e., changes in fracture permeability and porosity result in a corresponding change in fracture capillarity, it acts as a mitigating factor to the enhanced flow channeling demonstrated above. As a result, the outcome (as far as seepage is concerned) may be different. This is because a fracture with smaller porosity and permeability (because of excess precipitation) will now also have a stronger capillary suction. Flow into a partially blocked fracture (because of precipitation) may also imply gradual dissolution of the precipitates, gradually increasing (or restoring) the fracture porosity and permeability (which in turn reduces capillary suction). Thus, the presence of capillarity heterogeneity owing to THC processes may actually reduce the local flow 
channeling seen in simulations without consideration for such effects. Thus, seepage prediction (Spycher et al., 2005b; Mukhopadhyay et al., 2006) based on dynamic changes in porosity and permeability may be an overestimation of actual seepage, which can be estimated by considering dynamic changes in all the three hydrologic properties (porosity, permeability, and capillarity). We will discuss this more in Sections 4 and 5 .

\section{Modeling Approach and Methodology}

For the sake of brevity, the modeling tool used in this paper to investigate the impact of coupled THC processes on seepage will be hereafter referred to as the THC Seepage Model. A detailed description of the conceptual model underlying the THC Seepage Model may be found elsewhere (Sonnenthal et al., 2001; Sonnenthal et al., 2003; Spycher et al., 2003; Sonnenthal and Spycher, 2004; Spycher et al., 2004; Sonnenthal et al., 2005; Spycher et al. 2005a; Spycher et al., 2005b; Mukhopadhyay et al., 2006). The THC Seepage Model is based on the TOUGHREACT (Xu et al., 2004; $\mathrm{Xu}$ et al., 2006) reactive transport software. In this model, the unsaturated fractured rock is conceptualized as dual-permeability (Pruess, 1991), in which the rock matrix and the embedded fractures are modeled as separate but interacting continua. TH processes modeled with the TOUGHREACT (Xu et al., 2004; Xu et al., 2006) simulator are equivalent to those in TOUGH2 (Pruess, 1991; Pruess et al., 1999), a general-purpose simulator for multidimensional coupled fluid and heat flow of multiphase, multicomponent fluid mixtures in porous and fractured media. The geochemical module incorporated in TOUGHREACT simultaneously solves a set of chemical mass-action, kinetic-rate expressions for mineral dissolution/precipitation and mass-balance equations. This provides the extent of reaction and mass transfer between a set of given aqueous species, minerals, and gases at each gridblock of the flow model. Equations for heat, liquid and gas flow, aqueous and gaseous species transport, and chemical reactions are provided in (Xu et al., 2004; Xu et al., 2006).

\subsection{Model Domain}

Simulations were performed in a two-dimensional vertical cross section through the unsaturated fractured rock at Yucca Mountain, using the numerical grid shown in Figure 3. Since thermal perturbation arising out of repository heating is expected to occur over tens of meters above and below an emplacement tunnel, the vertical model domain comprises the entire unsaturated zone at Yucca Mountain (the model domain extends approximately $350 \mathrm{~m}$ above and below an emplacement tunnel). Such an approach ensures proper implementation of boundary conditions (see below). Vertically, the 
model domain consists of many layers, representing various stratigraphic layers of Yucca Mountain (there are 34 stratigraphic layers in total in the model domain). Each layer also has a matrix continuum and a fracture continuum. The emplacement tunnels will be located mainly in the lower lithophysal unit of Topopah Spring Tuff (Tptpll) stratigraphic unit, which is shown as tsw35 in Figure 3. The stratigraphic units just above and below are the middle nonlithophysal (Tptpmn) and lower nonlithophysal (Tptpln) of Topopah Spring tuff, respectively. These two units have been depicted as tsw34 and tsw36, respectively, in Figure 3.

The model domain extends $40.5 \mathrm{~m}$ laterally (or in the horizontal direction), extending from the center of one emplacement tunnel to the mid-point between two tunnels, which is treated as a vertical no-flow boundary. Symmetry is assumed with the symmetry plane parallel to the drift axis. The grid is radial (owing to the cylindrical geometry of the emplacement tunnel) and refined (with gridblocks as small as $0.2 \mathrm{~m}$ ) in the vicinity of the tunnel, but coarser farther away from the tunnels, gradually transforming into a rectangular grid. Tunnel radius is $2.75 \mathrm{~m}$, and the model domain has a thickness of $1 \mathrm{~m}$.

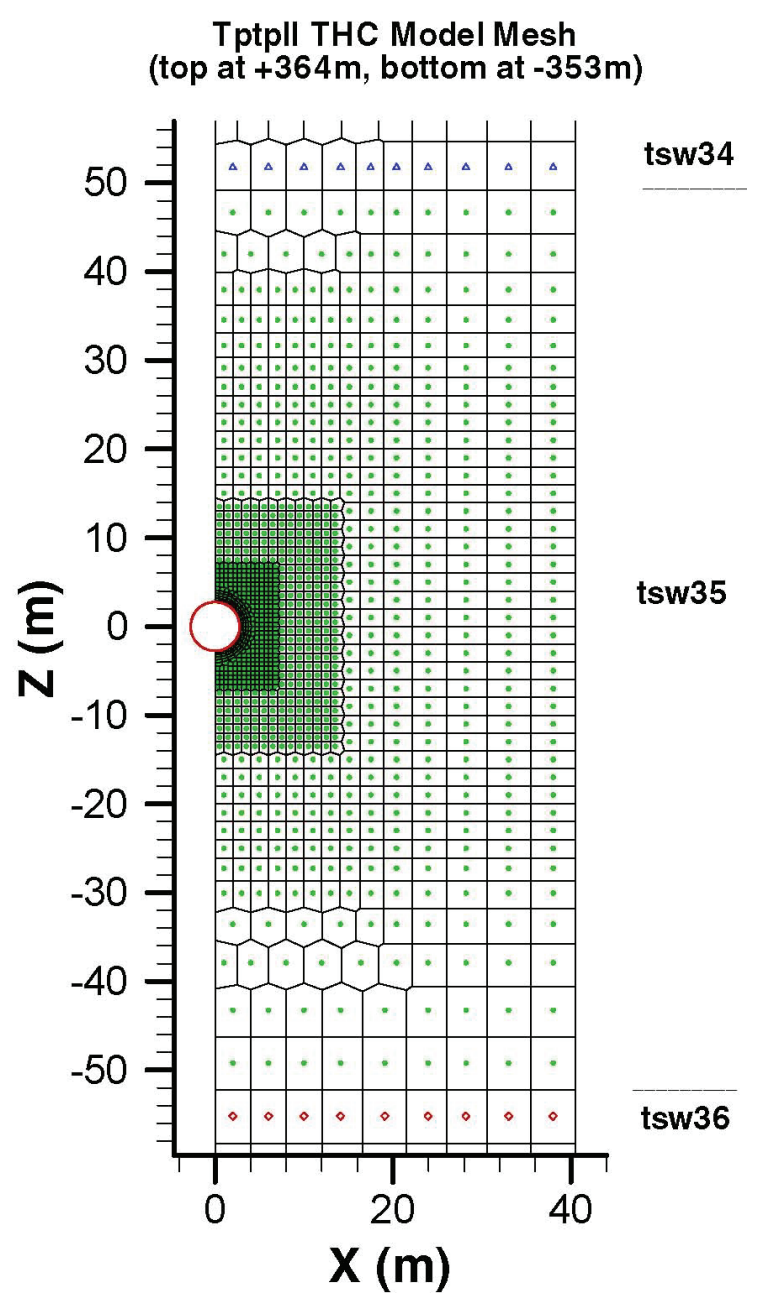


Figure 3. Two-dimensional numerical grid used in the simulations with the ambient, TH, and THC seepage models. The tunnel is located in the center of tsw35 (Tptpll). The units above and below are tsw34 (Tptpmn) and tsw36 (Tptpln), respectively. See Section 3.1 for further details

\subsection{Boundary and Initial Conditions}

The top boundary of the model is situated at the ground surface, whereas the bottom boundary coincides with the groundwater table. Both the top and bottom boundaries of the model are situated far away from the source of heat (i.e., the emplacement tunnel), and thermal perturbation is not expected to reach these boundaries. These boundaries are assigned Dirichlet-type conditions with fixed temperature, pressure, and liquid saturation values. The top boundary is treated as an open atmosphere with constant $\mathrm{CO}_{2}$

partial pressure and fixed composition of the percolating water. The groundwater table at the bottom of the model is represented as a flat, stable surface saturated with water and $\mathrm{CO}_{2}$ partial pressure at equilibrium. The lateral vertical boundaries are no-flow boundaries for flow, heat, and chemical fluxes. To provide initial thermal and hydrological conditions, a simulation was performed without reactive transport, heat load, or a tunnel (i.e., with rock at the location of the tunnel), until steady-state conditions were achieved.

\subsection{Thermal Load}

An initial thermal load of $1.45 \mathrm{~kW}$ per meter of tunnel length is applied for the TH and THC simulations in this paper. This thermal load is representative of the average heat-release conditions in the emplacement tunnels at Yucca Mountain. The thermal load decreases with time as a result of radioactive decay, as shown in Figure 4 (line in red). The figure also shows the current Yucca Mountain repository design, which considers forced tunnel ventilation over the first 50 years after emplacement. Such ventilation is expected to remove about $86 \%$ of the radioactive decay heat during those first 50 years, which is also shown in Figure 4. In short, the blue line in Figure 4 is the actual input thermal load for subsequent simulations.

\subsection{Infiltration Fluxes}

The ambient, TH, and THC simulations with the THC Seepage Model consider three long-term climate periods with constant net infiltration rate at the top of the model domain. These infiltration fluxes are 6 , 
16, and $25 \mathrm{~mm} /$ year (Houseworth, 2001), respectively, during 0-600, 600-2,000, and beyond 2,000 years (Campbell et al., 2004). Simulations performed with these infiltration fluxes will be denoted as PMF1 (representing infiltration multiplication factor of 1). Additional infiltration scenarios have been investigated with the THC Seepage Model to cover the range of variability in the infiltration fluxes within the repository horizon.

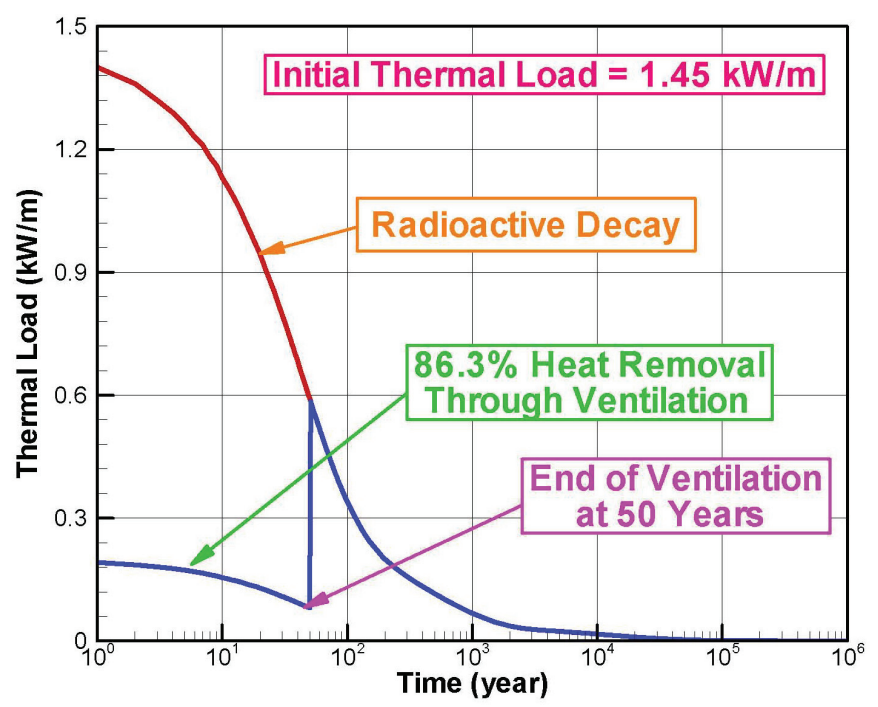

Figure 4. Transient thermal loading history of the emplaced wastes at Yucca Mountain. Note that 86.3\% of the generated heat is expected to be removed by ventilation during the first 50 years after emplacement. The blue line represents the actual heat input into the simulations

\subsection{Initial Heterogeneous Fracture Permeability Distribution}

Fracture permeability of the rock in the vicinity of the emplacement tunnels is one of the key parameters for seepage. Geostatistical information on the variability of fracture permeability in the Tptpll stratigraphic unit is available from air-injection measurements in boreholes. The measured permeability data show a four-order-of-magnitude variability in space, with an arithmetic average of standard deviation in $\log 10$ space of all air-permeability measurements of 0.91 (Tsang et al., 2004). Consistent with this measured data, the heterogeneous fracture permeability distribution used in this paper is developed with a standard deviation of 1.0 in the $\log 10$ space. The mean fracture permeability of various stratigraphic units is obtained from (Ghezzehai and Liu, 2004). 
Using the specified mean and standard deviation, a log-normal distribution of fracture permeabilities is generated. The choice of a log-normal distribution for fracture permeability is consistent with previous seepage studies (Tsang et al., 2004). Spatial correlation length is set to $0.3 \mathrm{~m}$, consistent again with previous seepage studies (Tsang et al., 2004). Three realizations of the heterogeneous fracture permeability fields were generated, each based on the same cumulative distribution function but with a different seed number for the random number generator. The cumulative distribution function was obtained through analysis of air-permeability testing, as found in (Tsang et al., 2004). One realization (Realization \#1) of the heterogeneous fracture permeability field used in this paper is shown in Figure 5.

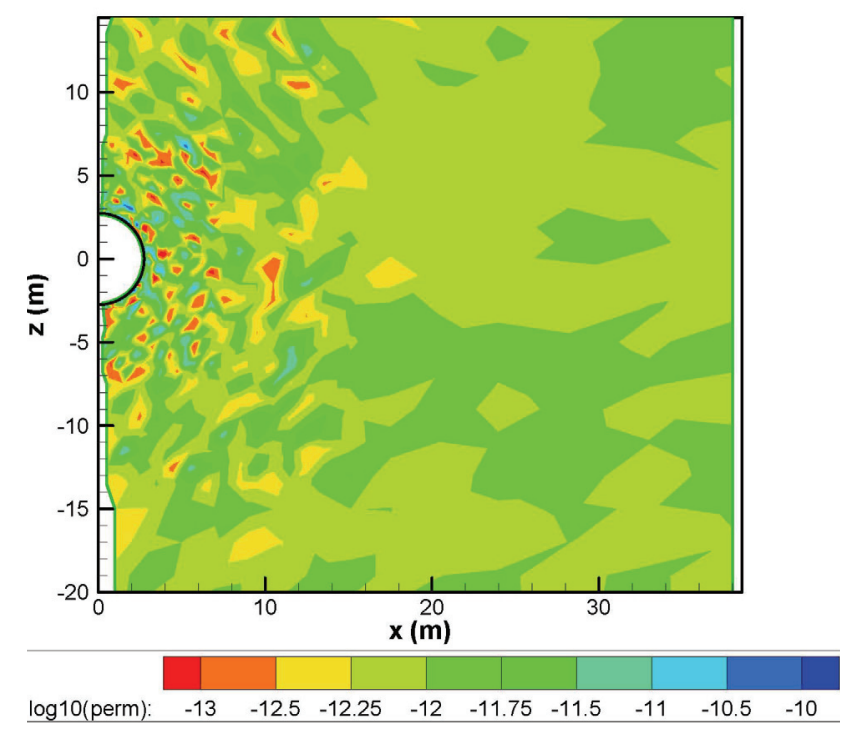

Figure 5. The initial permeability (in $\mathrm{m}^{2}$ ) distribution (Realization \#1) used in ambient, TH, and THC simulations.

\subsection{Fracture Capillary Strength Parameter}

The fracture capillary strength parameter $(1 / \alpha)$ used in this paper is based on calibration to seepage data from liquid-release tests (Finsterle et al., 2004) at the Exploratory Studies Facility (ESF) of Yucca Mountain. Data from six liquid-release tests are available in the potential host rock (Tptpll) of Yucca Mountain. Based on these data, the spatial variability of the fracture capillary strength parameter in Tptpll is described in (Birkholzer, 2004). The mean 1/ $\alpha$-value for all Tptpll measurements is $591 \mathrm{~Pa}$, as given in (Birkholzer, 2004). However, the actual value used in the simulations in this paper is $589 \mathrm{~Pa}$, which is slightly smaller ( $\sim 1.2$ percent) than the measured mean value. The latter value was adopted for 
the sake of consistency with previous thermal seepage studies (Birkholzer et al., 2004) and is not expected to cause any significant change in the findings presented in this paper.

The calibration process (Finsterle et al., 2004) that was used to obtain the above mean fracture $(1 / \alpha)$ parameter ignored the impact of permeability heterogeneity on capillarity. In other words, calibration was performed without consideration to Leverett scaling (Leverett 1941). When the mean fracture $(1 / \alpha)$ of $589 \mathrm{~Pa}$ is used in a simulation that includes Leverett scaling, we observe seepage at all times even under ambient conditions (i.e., when there are no TH or THC changes). There is no evidence of persistent seepage under ambient conditions at Yucca Mountain. As a result, simulations were performed with Leverett scaling (Equation 7) to obtain the minimum value of the fracture $(1 / \alpha)$ parameter that will not produce seepage under ambient conditions. It is estimated that a fracture $(1 / \alpha)$ value of $1,800 \mathrm{~Pa}$ is needed for this purpose. Thus, consistent with the field observation of no seepage under ambient conditions, a fracture $(1 / \alpha)$ parameter of $1,800 \mathrm{~Pa}$ was selected for the simulations with Leverett scaling (Leverett, 1941) in this paper.

\subsection{Rock Properties}

Except for the fracture 1/ $\alpha$ parameter of the Tptpll unit, all thermal and hydrological properties for the fracture and matrix continua of the various stratigraphic units in the model domain are obtained from Ghezzehei and Liu (2004). The mean of the fracture permeability of various units is also obtained from Ghezzehei and Liu (2004). Most of the layer-averaged hydrologic properties are based on calibration against borehole measurements such as saturation data, water-potential data, pneumatic pressure data, and ambient temperature data. Thermal properties are based on measured data from site-specific core samples. A summary of the key thermal and hydrological properties for the Tptpll unit (the host rock for the emplacement tunnels) is provided in Table 1.

Table 1. Key hydrological and thermal properties of the host rock Tptpll (Ghezzehei and Liu, 2004)

\begin{tabular}{|l|l|r|}
\hline Property Name & Variable Name and Units & Value \\
\hline \multicolumn{2}{|c|}{ Matrix Continuum } & $0.4480 \times 10^{-17}$ \\
\hline Permeability & $k_{m}\left(\mathrm{~m}^{2}\right)$ & 0.1486 \\
\hline Porosity & $\phi_{m}(-)$ & 92593 \\
\hline van Genuchten $1 / \alpha$ & $1 / \alpha_{m}(\mathrm{~Pa})$ & 0.2160 \\
\hline van Genuchten $\mathrm{m}$ & $m_{m}(-)$ & \\
\hline
\end{tabular}




\begin{tabular}{|c|c|c|}
\hline Residual saturation & $S_{m}^{l r}(-)$ & 0.1200 \\
\hline Rock grain density & $\rho_{g}\left(\mathrm{~kg} / \mathrm{m}^{3}\right)$ & 2326 \\
\hline Rock grain specific heat capacity & $C_{p m}\left(\mathrm{~J} \mathrm{~kg}^{-1} \mathrm{~K}^{-1}\right)$ & 985 \\
\hline Bulk dry thermal conductivity & $\lambda_{d r y}\left(\mathrm{~W} \mathrm{~m}^{-1} \mathrm{~K}^{-1}\right)$ & 1.2780 \\
\hline Bulk wet thermal conductivity & $\lambda_{\text {wet }}\left(\mathrm{W} \mathrm{m}^{-1} \mathrm{~K}^{-1}\right)$ & 1.8900 \\
\hline \multicolumn{3}{|c|}{ Fracture Continuum } \\
\hline Mean permeability & $k_{f}\left(\mathrm{~m}^{2}\right)$ & $0.9120 \times 10^{-12}$ \\
\hline Porosity & $\phi_{f}(-)$ & $0.9600 \times 10^{-2}$ \\
\hline $\begin{array}{l}\text { van Genuchten }(1 / \alpha) \text { from liquid release } \\
\text { tests [9]; see also Section } 2.6\end{array}$ & $1 / \alpha_{0}(\mathrm{~Pa})$ & 589 \\
\hline $\begin{array}{l}\text { van Genuchten }(1 / \alpha) \text { for simulations with } \\
\text { Leverett scaling (Equation } 7)\end{array}$ & $1 / \alpha_{0}(\mathrm{~Pa})$ & 1,800 \\
\hline van Genuchten $m$ & $m_{f}(-)$ & 0.6330 \\
\hline Residual saturation & $S_{f}^{l r}(-)$ & 0.01 \\
\hline Coefficient for active fracture model & $\gamma(-)$ & 0.5690 \\
\hline Standard deviation of $\log 10$ permeability & $\sigma_{f}(-)$ & 1.0 \\
\hline
\end{tabular}




\subsection{Geochemical Input Parameters}

Model input data relating to chemical processes were the same as in (Spycher et al., 2005a; Spycher et al., 2005b; Mukhopadhyay et al., 2006) (also essentially the same as in Spycher et al., 2003). The porewater composition input into the model was taken from analyses of pore water extracted by ultracentrifugation of core samples. The initial water was assumed to have the same chemical composition as in the rock matrix and fractures (Table 2). Iron, aluminum, and total aqueous carbonate concentrations (hereafter listed as $\mathrm{HCO}_{3}{ }^{-}$) were not measured and were calculated as shown in Table 2.

Solid phases and primary aqueous species included in the model are shown in Table 3. Secondary aqueous species (i.e., ion pairs/complexes that can be derived, through a mass-action law, from the primary components) were also considered (34 in total). Initial mineral abundances in the host rock (Tptpll) are shown (volume \% solid), with blank values indicating secondary minerals (italics) not initially present but allowed to form. Glass and hematite were not present in modeled geologic units around the drift but occurred in other modeled units. Minerals were assumed to react at equilibrium (Eq) or under kinetic constraints (Kin), with only some of them allowed to dissolve (Kin D). Reactions between aqueous species and gases were assumed to proceed at equilibrium, whereas minerals were set to react either under equilibrium or kinetic constraints (Xu et al., 2004; Xu et al., 2006) as listed in Table 3. Kinetic and thermodynamic data were taken from numerous literature sources (Spycher et al., 2003), with many equilibrium constants adopted from the SUPCRT92 package (Johnson et al., 1992).

Table 2. Initial Water Composition in fractures (F), matrix (M), and infiltration (I) waters ${ }^{(1)}$

\begin{tabular}{|c|c|c|c|}
\hline Parameters & Units & Concentration & Water \\
\hline $\mathrm{pH}$ & $\mathrm{pH}$ Units & $\begin{array}{c}8.32\left(\text { at } 25^{\circ} \mathrm{C}\right) \\
7.75\left(\text { at } 17^{\circ} \mathrm{C}\right)\end{array}$ & $\mathrm{F}, \mathrm{M}$ \\
& & 61.3 & $\mathrm{I}, \mathrm{M}, \mathrm{I}$ \\
\hline $\mathrm{Na}^{+}$ & $\mathrm{mg} / \mathrm{L}$ & 70.5 & $\mathrm{~F}, \mathrm{M}, \mathrm{I}$ \\
\hline $\mathrm{SiO}_{2}(\mathrm{aq})$ & $\mathrm{mg} / \mathrm{L}$ & 101 & $\mathrm{~F}, \mathrm{M}, \mathrm{I}$ \\
\hline $\mathrm{Ca}^{2+}$ & $\mathrm{mg} / \mathrm{L}$ & 8.0 & $\mathrm{~F}, \mathrm{M}, \mathrm{I}$ \\
\hline $\mathrm{K}^{+}$ & $\mathrm{mg} / \mathrm{L}$ & & \\
\hline
\end{tabular}




\begin{tabular}{|c|c|c|c|}
\hline $\mathrm{Mg}^{2+}$ & $\mathrm{mg} / \mathrm{L}$ & 17 & $\mathrm{~F}, \mathrm{M}, \mathrm{I}$ \\
\hline $\mathrm{Al}^{3+}$ & $\mathrm{mg} / \mathrm{L}$ & $1.67 \times 10^{-5(3)}$ & $\mathrm{F}, \mathrm{M}$ \\
& & $2.64 \times 10^{-6(4)}$ & $\mathrm{I}$ \\
\hline $\mathrm{Fe}^{3+}$ & $\mathrm{mg} / \mathrm{L}$ & $6.46 \times 10^{-8(5)}$ & $\mathrm{F}, \mathrm{M}$ \\
& & $2.88 \times 10^{-8}(6)$ & $\mathrm{I}$ \\
\hline $\mathrm{HCO}_{3}{ }^{-}$ & $\mathrm{mg} / \mathrm{L}$ & $200^{(7)}$ & $\mathrm{F}, \mathrm{M}$ \\
& & $216^{(2)}$ & $\mathrm{I}$ \\
\hline $\mathrm{Cl}^{-}$ & $\mathrm{mg} / \mathrm{L}$ & 117 & $\mathrm{~F}, \mathrm{M}, \mathrm{I}$ \\
\hline $\mathrm{SO}_{4}{ }^{2-}$ & $\mathrm{mg} / \mathrm{L}$ & 116 & $\mathrm{~F}, \mathrm{M}, \mathrm{I}$ \\
\hline $\mathrm{F}^{-}$ & $\mathrm{mg} / \mathrm{L}$ & 0.86 & $\mathrm{~F}, \mathrm{M}, \mathrm{I}$ \\
\hline
\end{tabular}

NOTES: ${ }^{(1)}$ Average porewater composition (Sonnenthal et al., 2005). ${ }^{(2)} \mathrm{HCO}_{3}{ }^{-}$calculated from equilibrium with $\log \left(\mathrm{P}_{\mathrm{CO} 2}\right)=-2.5$, and $\mathrm{pH}$ adjusted until charge balance was obtained.

${ }^{(3)}$ Calculated by equilibrating with illite at $25^{\circ} \mathrm{C}$ and $\mathrm{pH} 8.32 .{ }^{(4)}$ Calculated by equilibrating with illite at $17^{\circ} \mathrm{C}$ and $\mathrm{pH} 7.75$. ${ }^{(5)}$ Calculated by equilibrating with hematite at $25^{\circ} \mathrm{C}$ and $\mathrm{pH} 8.32$. ${ }^{(6)}$ Calculated by equilibrating with hematite at $17^{\circ} \mathrm{C}$ and $\mathrm{pH} 7.75$. ${ }^{(7)}$ Total aqueous carbonate as $\mathrm{HCO}_{3}{ }^{-}$, calculated from charge balance.

\subsection{Porosity-Permeability Relationship}

While several porosity-permeability relationships are available in TOUGHREACT (Xu et al., 2004; Xu et al., 2006), the following approach is adopted for the simulations in this paper. The initial hydraulic aperture of a fracture is calculated using a cubic law of the form

$$
b_{0, h}=\left[12 k_{0, f} s\right]^{\frac{1}{3}}
$$

The fracture permeability resulting from a change in fracture hydraulic aperture is computed as

$$
k_{f}=\frac{\left[b_{0, h}+\Delta b\right]^{3}}{12 s}
$$


The change in hydraulic aperture, $\Delta b$, can be approximated from

$$
\Delta b=\frac{\phi_{f}-\phi_{0, f}}{\phi_{0, f}} b_{g}
$$

The matrix permeability is correlated to porosity changes through the Carman-Kozeny relationship (Carman, 1937; Panda and Lake, 1994)

$$
k_{m}=k_{m, 0} \frac{\left(1-\phi_{0, m}\right)^{2}}{\left(1-\phi_{m}\right)^{2}}\left(\frac{\phi_{m}}{\phi_{0, m}}\right)^{3}
$$

\begin{tabular}{|c|c|c|c|c|}
\hline $\begin{array}{l}\text { Primary } \\
\text { Aqueous } \\
\text { Species }^{1}\end{array}$ & Minerals $^{1}$ & $\begin{array}{c}\text { Initial } \\
\text { Vol \% } \\
\text { Matrix }\end{array}$ & $\begin{array}{c}\text { Initial } \\
\text { Vol \% } \\
\text { Fractur } \\
\text { es }\end{array}$ & $\begin{array}{c}\text { Reactio } \\
\mathbf{n}\end{array}$ \\
\hline $\mathrm{H}_{2} \mathrm{O}$ & Calcite & 0.04 & 2 & $\mathrm{Eq}$ \\
\hline $\mathrm{H}^{+}$ & Tridymite & 2.3 & 1.4 & Kin D \\
\hline $\mathrm{Na}^{+}$ & $\begin{array}{l}\text { Cristobalite- } \\
\mathrm{a}\end{array}$ & 19 & 11 & Kin D \\
\hline $\mathrm{K}^{+}$ & Quartz & 14 & 8.5 & Kin D \\
\hline $\mathrm{Ca}^{2+}$ & $\begin{array}{l}\text { Amorphous } \\
\text { Silica }\end{array}$ & & & Kin \\
\hline $\mathrm{Mg}^{2+}$ & Hematite & & & Kin D \\
\hline $\mathrm{SiO}_{2}$ & Fluorite & 0.01 & 0.01 & Kin \\
\hline $\mathrm{AlO}_{2}^{-}$ & Gypsum & & & $\mathrm{Eq}$ \\
\hline $\mathrm{HFeO}_{2}$ & Albite & 26 & 16 & Kin \\
\hline $\mathrm{HCO}_{3}^{-}$ & K-feldspar & 35 & 21 & Kin \\
\hline $\mathrm{Cl}^{-}$ & Anorthite & 0.9 & 0.5 & Kin D \\
\hline $\mathrm{SO}_{4}^{2-}$ & Ca-Smectite & 0.7 & 2 & Kin \\
\hline
\end{tabular}

Table 3. Primary aqueous species (components), minerals, and gases included in simulations 


\begin{tabular}{|c|l|r|r|c|}
\hline $\mathrm{F}^{-}$ & Mg-Smectite & 0.7 & 2 & Kin \\
& Na-Smectite & 0.3 & 0.8 & Kin \\
\hline Gases & Illite & 0.5 & 1.5 & Kin \\
\hline $\mathrm{CO}_{2}$ & Kaolinite & & & Kin \\
$\mathrm{H}_{2} \mathrm{O}$ & Opal-CT & 1 & 1 & Kin D \\
Air & Stellerite & & 32 & Kin \\
& Heulandite & 0.002 & 0.001 & Kin \\
& Mordenite & 0.001 & & Kin \\
& Clinoptilolit & 0.005 & 0.003 & Kin \\
& e & & & \\
& Glass & & & Kin D \\
& & & & \\
\hline
\end{tabular}

${ }^{1}$ The following salts were also allowed to form upon complete evaporation, through a normative computation, then allowed to dissolve (full dissociation) upon rewetting: $\mathrm{NaCl}, \mathrm{NaNO}_{3}, \mathrm{KCl}, \mathrm{KNO}_{3}$, $\mathrm{MgSO}_{4}, \mathrm{~K}_{2} \mathrm{SO}_{4}, \mathrm{Na}_{2} \mathrm{SO}_{4}$

\section{Results and Discussion}

\subsection{Evolution of TH and THC Processes}

To illustrate the impact of THC-induced changes in fracture porosity and permeability only, we first present results from simulations performed without consideration to capillarity heterogeneity (i.e., changes in capillarity caused by changes in permeability and porosity are ignored). Figure 6 shows the contours of fracture saturation from the TH simulations (i.e., fracture permeability and porosity does not change with time) at 600 and 2,000 years. The same figure also shows the temperatures (solid black lines) and the (liquid) flux vectors (by arrows) in the fractures. At 600 years (Figure 6a), a large dryout zone exists above and below the emplacement tunnel. Outside the dryout zone, a small condensation zone appears where the fracture saturations are elevated from their ambient saturations (i.e., saturations before start of heating). Far away from the emplacement tunnel, the fracture saturation is essentially ambient. Note that because of the heterogeneities in the fracture permeability field, there are small local zones of increased or decreased saturations. 

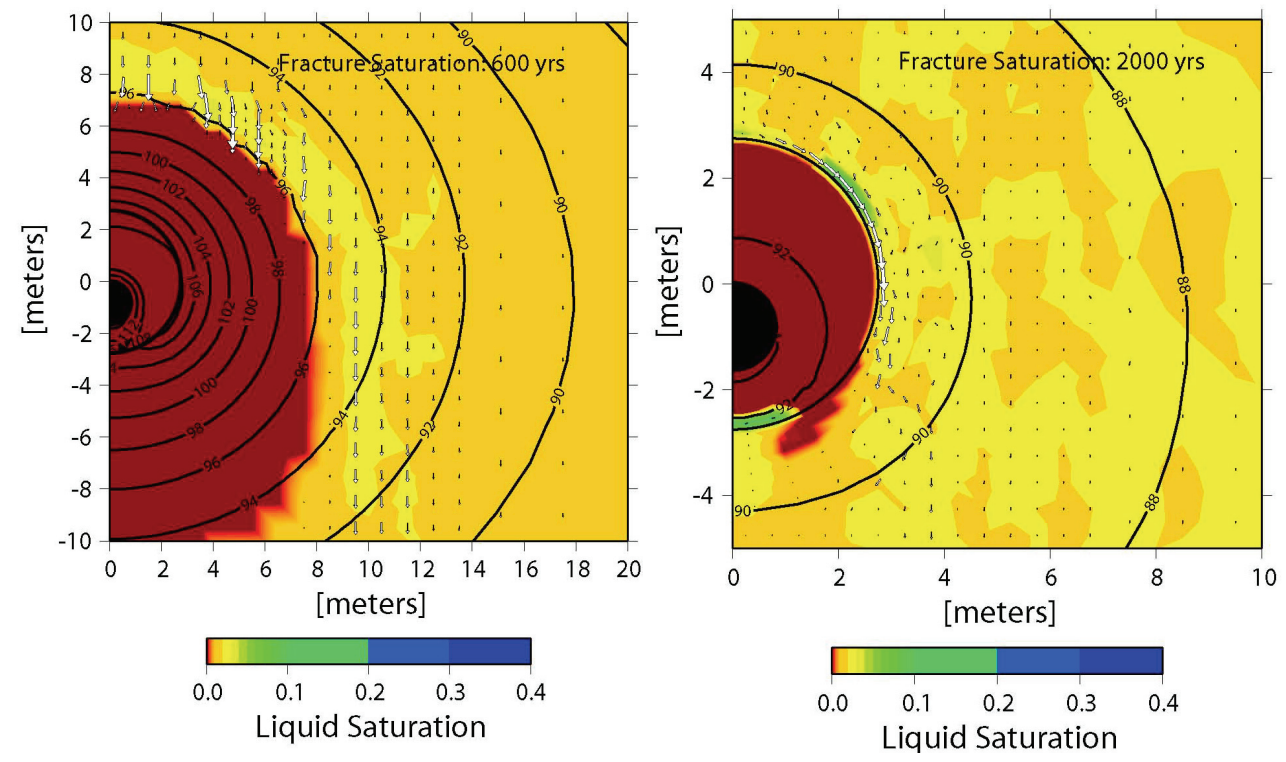

Figure 6. Contours of temperature, liquid saturation, and liquid flux vectors in the vicinity of the emplacement tunnels in TH simulations with infiltration fluxes of PMF1: (a) 600 years (left) and (b) 2,000 years (right)

At 600 years, the fracture liquid flux vectors (Figure 6a) show that downward flow is diverted around the dryout zone. As we move laterally away from the drift, the flux vector field is essentially unperturbed (i.e., flow is vertically downwards resulting from infiltration fluxes applied at the top model boundary). With time, the dryout zone recedes, and flow is diverted at the edges of the continuously shrinking dryout zone. Figure $6 \mathrm{~b}$ shows the saturation and flux vectors at 2,000 years, when the dryout zone has disappeared completely and flow in fractures is diverted along the periphery of the emplacement tunnel. Observe that no localized flow channeling is visible in Figure 6. Because of the small infiltration fluxes (multiplication factor of 1) used in this simulation, fracture saturations in the rock elements just above the emplacement tunnel do not build up substantially enough to overcome the capillary barrier effect, i.e., the saturation in those elements remain below the threshold saturation of seepage for TH simulations (see Equation 10) at all times.

The impact of the THC processes on the flow field in the tunnel vicinity can be observed in Figure 7. Similar to Figure 6, Figure 7 shows the contours of temperature, saturation, and the liquid flux vectors near emplacement tunnels at 600 (Figure 7a) and 2,000 years (Figure 7b). As shown by the white arrows in Figure 7a, flow is diverted around the dryout zone at 600 years. The distribution of flux in Figure 7a 
is not too different from that in Figure 6a. However, the flux distribution pattern in Figures $7 \mathrm{~b}$ is different from that in Figures $6 \mathrm{~b}$. While no flow channeling is observed in Figure 6b (with TH simulations), flow channeling at local scales is visible just above the tunnel in Figure $7 \mathrm{~b}$. 


\subsection{Permeability Changes From THC Processes}

Mineral alteration and evolution of pore water chemistry around waste emplacement tunnels have been investigated in (Sonnenthal et al., 2001; Sonnenthal et al., 2003; Spycher et al., 2003; Sonnenthal and Spycher, 2004; Spycher et al., 2004; Sonnenthal et al., 2005; Spycher et al. 2005a; Spycher et al., 2005b; Mukhopadhyay et al., 2006). In summary, an overall fracture permeability decrease is predicted, caused primarily by the precipitation of amorphous silica through evaporative concentration at the boiling front. Calcite precipitation also occurs directly through evaporative concentration, or indirectly through the volatilization of $\mathrm{CO}_{2}$ from the aqueous phase during boiling and evaporation (e.g., $\mathrm{CaCO}_{3(\mathrm{~s})}+\mathrm{CO}_{2(\mathrm{~g})}+$ $\mathrm{H}_{2} \mathrm{O}<==\mathrm{Ca}^{++}+2 \mathrm{HCO}_{3}{ }^{-}$), as well as through the decrease in calcite solubility with increasing temperature. It has been observed that the precipitated amounts of calcite are typically smaller by about one order of magnitude (by volume) than the silica amounts. Evaporite minerals (such as anhydrite, gypsum, or halite) also precipitate as a result of dryout, but their contribution to the decrease in fracture permeability is understood to be limited and only temporary, as these salts rapidly redissolve upon the collapse of the boiling front. The alteration of primary feldspars to clays and zeolites (e.g., 2.33 $\mathrm{NaAlSi}_{3} \mathrm{O}_{8}$ (albite) $+2 \mathrm{H}^{+}<==\mathrm{Na}_{0.33} \mathrm{Al}_{2.33} \mathrm{Si}_{3.67} \mathrm{O}_{10}(\mathrm{OH})_{2}$ (smectite) $+3.32 \mathrm{SiO}_{2}+2 \mathrm{Na}^{+}$and $2 \mathrm{NaAlSi}_{3} \mathrm{O}_{8}$ (albite) $+\mathrm{SiO}_{2}+\mathrm{CaCO}_{3}$ (calcite) $+\mathrm{H}^{+}+7 \mathrm{H}_{2} \mathrm{O}<==>\mathrm{CaAl}_{2} \mathrm{Si}_{7} \mathrm{O}_{18} \cdot 7 \mathrm{H}_{2} \mathrm{O}$ (stellerite) + $2 \mathrm{Na}^{+}+\mathrm{HCO}_{3}^{-}$) affects the pore-water chemistry, notably $\mathrm{pH}$, calcium, and sodium concentrations, but does not proceed to a large enough extend to alter significantly either the fracture or matrix permeability.
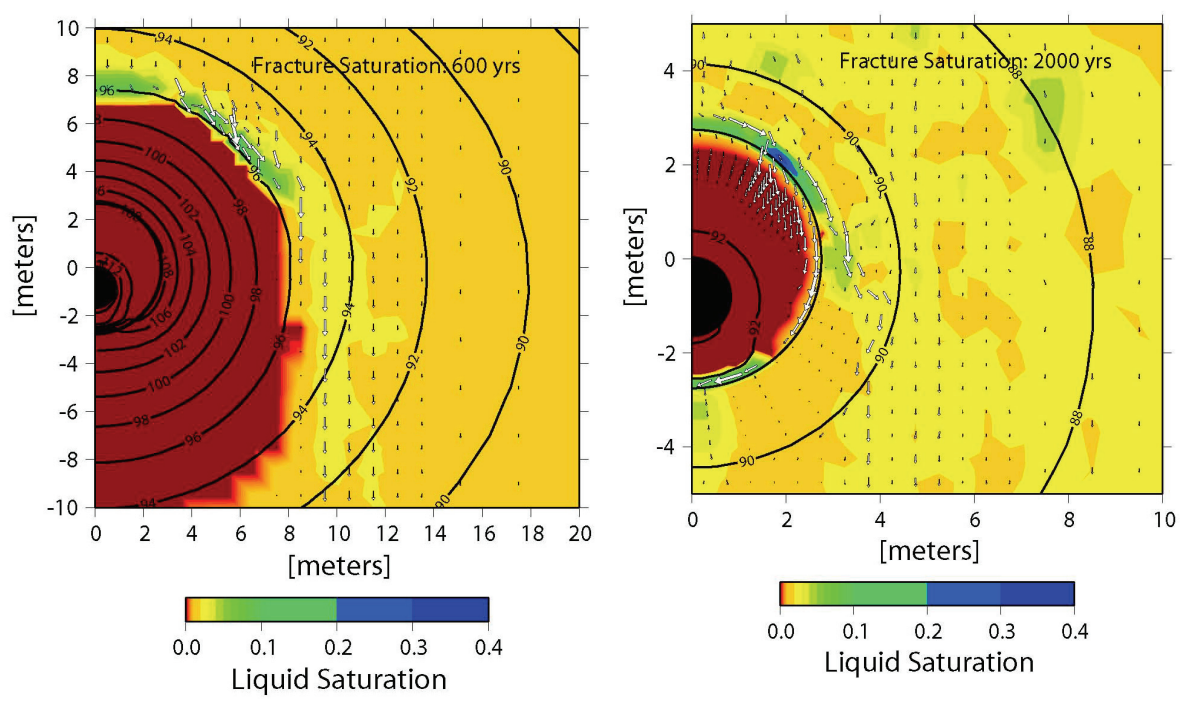
Figure 7. Contours of temperature and liquid saturation, and liquid flux vectors in the vicinity of the emplacement tunnels in THC simulations with infiltration fluxes of PMF1: (a) 600 years (left) and (b) 2,000 years (right)

Dynamic fracture-permeability field changes in THC simulations can be seen in Figure 8. Again, Leverett scaling has not been considered for these results. Contours of fracture permeability at 600 (Figure 8a) and 2,000 (Figure 8b) years demonstrate the evolution of mineral precipitation and dissolution processes. Observe that at 600 years (Figure 8a), there existed an "umbrella" of reduced permeability just outside the boiling front (Figure 7a). The precipitation front follows the boiling front, and as the latter collapses, it ends up at the tunnel wall (Figure 8b).

To illustrate this more clearly, the evolution of fracture permeability with time in the gridblocks just above the emplacement tunnel is shown in Figure 9. In the numerical grid shown in Figure 3, there are 12 gridblocks between the tunnel crown and the tunnel springline (Figure 2). The location of each gridblock is described in terms of its radial position with respect to the vertical axis, with $\theta=0^{\circ}$ representing the tunnel crown and $\theta=90^{\circ}$ representing the springline. Figure 9 shows the transient pattern of fracture permeabilities in these gridblocks. There are no permeability changes in these twelve grid blocks till about 1,600 years. After that time, permeabilities decrease rapidly in most of the gridblocks. The reduction in permeability in some gridblocks is as large as six orders of magnitude. This kind of reduction in permeability is visible through 2,000 years (see below for more discussion on this). After 2,000 years, permeabilities of most of the gridblocks return close to their original (or ambient) values. This increase in fracture permeability after 2,000 years occurs because the fractures rewet (with more water coming in through enhanced infiltration fluxes), and soluble undersaturated minerals such as gypsum and various salts are dissolved. 

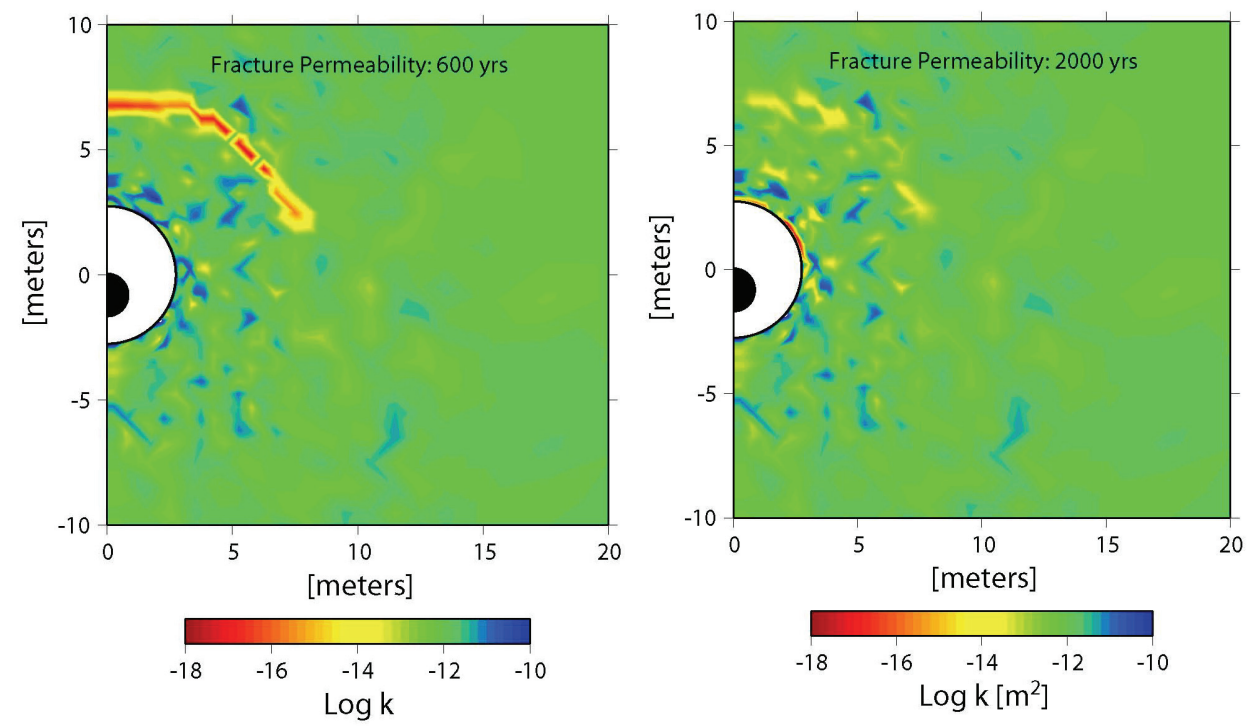

Figure 8. Contours of fracture permeability for the simulations described in Figure 7: (a) 600 years (left) and (b) 2,000 years (right)

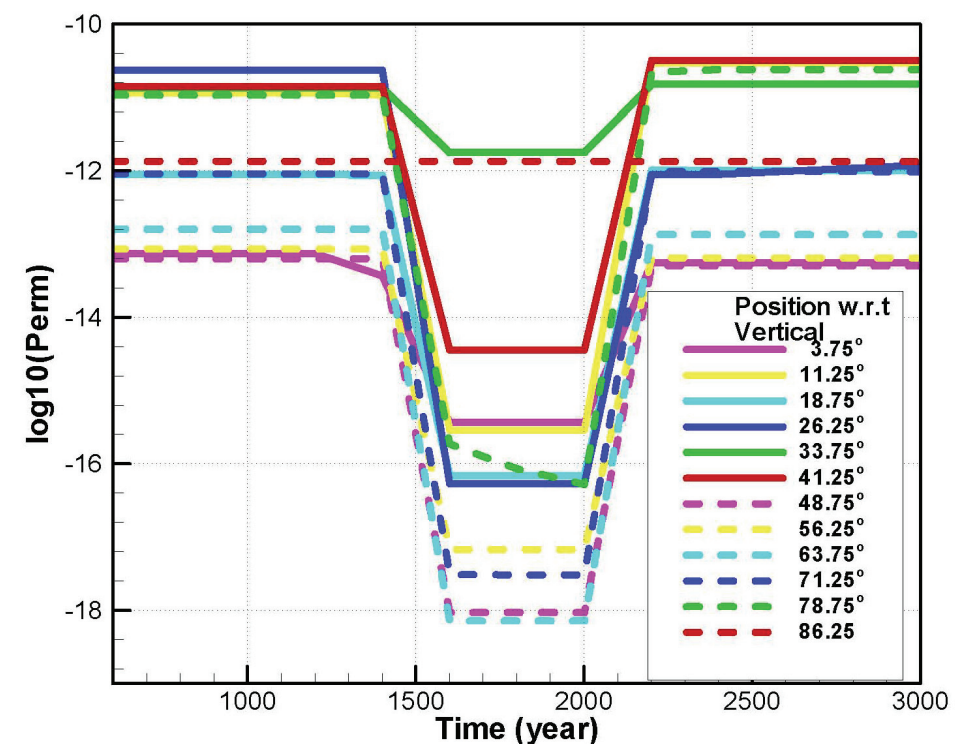

Figure 9. Fracture permeabilities of the last gridblocks above the emplacement tunnels as a function of time for the simulations described in Figure 7. The different lines represent the locations $\left(\theta_{i}\right)$ of gridblocks just above the emplacement tunnel with respect to the vertical (see Figure 2)

The permeability decrease is a strong function of the permeability-porosity coupling relationship used in the simulations (Equations 11-14), which relies on parameters such as fracture spacing, surface area, and initial permeability. Because the relationship is based on a reduction in hydraulic aperture, the permeability decreases slowly upon initial precipitation of minerals, but decreases rapidly when only a small amount of mineral precipitation is sufficient to block the flow almost entirely (Figure 10). The overall effect is that for fracture permeabilities at and above mean values, the bulk of porosity reduction 
(by precipitation of amorphous silica and calcite) affects the permeability by no more than two orders of magnitude (Figure 10). In contrast, the large temporary decrease in permeability from about two to six 
orders of magnitude results from precipitated minerals (gypsum and salt) that is about half (or less) the volume of previously deposited minerals (amorphous silica and calcite). The permeability decrease can also be a strong function of the initial fracture porosity when small fracture porosities translate to small fracture apertures (rather than large fracture spacing). Therefore, uncertainties in fracture properties such as initial porosity, permeability, spacing, and surface area will affect the response of the model, from almost no permeability decrease to complete plugging of fractures. However, the heterogeneity in fracture permeability input into the simulations is likely to encompass the uncertainty in other fracture properties, such that the results shown here can be regarded as encompassing these uncertainties.

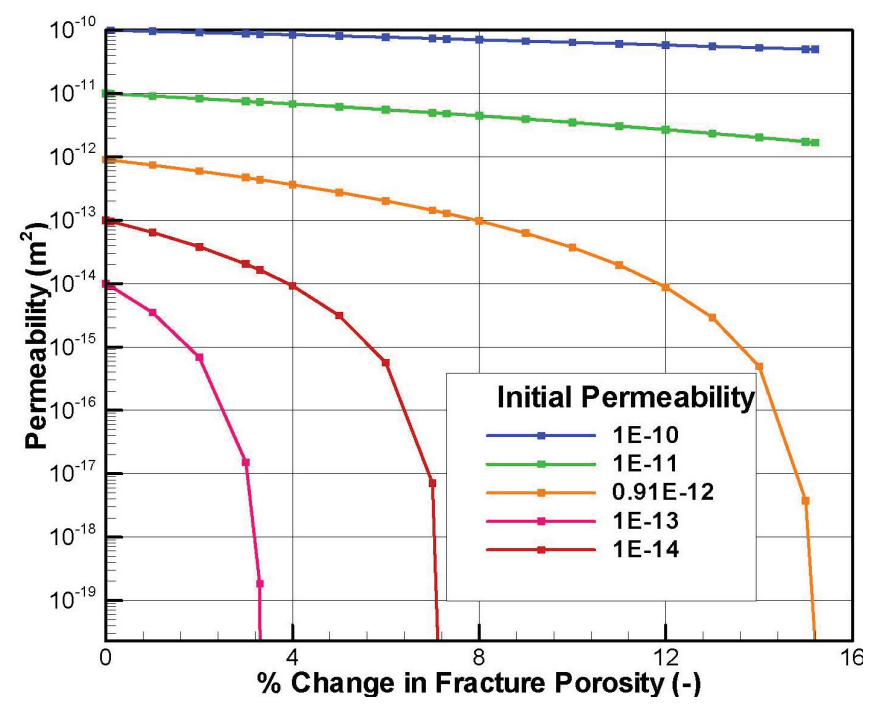

Figure 10. Fracture permeability as a function of porosity (see Equations 11-14) decrease for various values of initial fracture permeability

\subsection{Seepage Under Ambient, TH, and THC Conditions}

The amount and duration of seepage into the emplacement tunnels from the THC simulations without Leverett scaling are shown in Figure 11. The seepage fluxes shown in Figure 11 are averaged over the emplacement tunnel footprint area, i.e., over a rectangular area of $2.75 \mathrm{~m}$ (the tunnel radius) wide times $1 \mathrm{~m}$ thick. As shown in Figure 11, seepage occurs between 1,400 and 2,000 years, and the maximum predicted seepage rate is $\sim 10 \mathrm{~mm} /$ year. Seepage does not occur in the ambient and TH simulations. Recall that the infiltration fluxes for this simulation are 6, 16, and $25 \mathrm{~mm} /$ year, respectively, for 0-600, 600-2,000, and beyond 2,000 years. These infiltration fluxes are also shown in Figure 11. 
The results presented thus far provide examples of how the feedback of THC processes on porosity and permeability (without consideration to resulting capillarity changes) in unsaturated fractured rock influences the flow paths of water percolating from the top as it approaches the emplacement tunnel. For the specific simulation discussed here, the alteration in flow paths and subsequent flow channeling was enough to cause seepage, while no seepage occurred when the THC processes were ignored (i.e., in ambient or TH simulations). 


\subsection{Feedback of Dynamic Capillarity Changes on Seepage}

As indicated by Equation 7, changes in permeability and porosity (caused by mineral precipitation and dissolution) have a corresponding impact on capillarity. Since capillarity is one of the parameters having a strong influence on seepage (or its absence), the feedback of THC processes on capillarity needs careful evaluation. In the results presented so far this aspect has not been included. The impact of dynamically changing capillarity on flow patterns around emplacement tunnels can be seen from Figure 12 (compare with Figure 7). Figure 12 shows contours of temperature and liquid saturation in fractures at 600 years (Figure 12a) and 2,000 years (Figure 12b). It also shows the liquid flux vectors.

In contrast to THC simulations (Figure 11), where changes in capillarity resulting from changes in porosity and permeability were ignored, no seepage is observed when such effects are included. This is because when deposition occurs in a fracture and its permeability decreases, if changes in capillarity are ignored, flow is mostly diverted away from that fracture to a fracture with more permeability (i.e., less deposition). This results in local flow channeling, leading to seepage. However, reduction in permeability is also associated with a corresponding increase in capillary suction. Thus, flow diversion from fractures with more deposition is not as severe as predicted by models where dynamic changes in capillarity are ignored. In other words, less local flow channeling may be predicted when dynamic changes in capillarity are accounted for in the THC models. This also implies that prediction of seepage by such models where capillarity changes are ignored may be overestimated. 


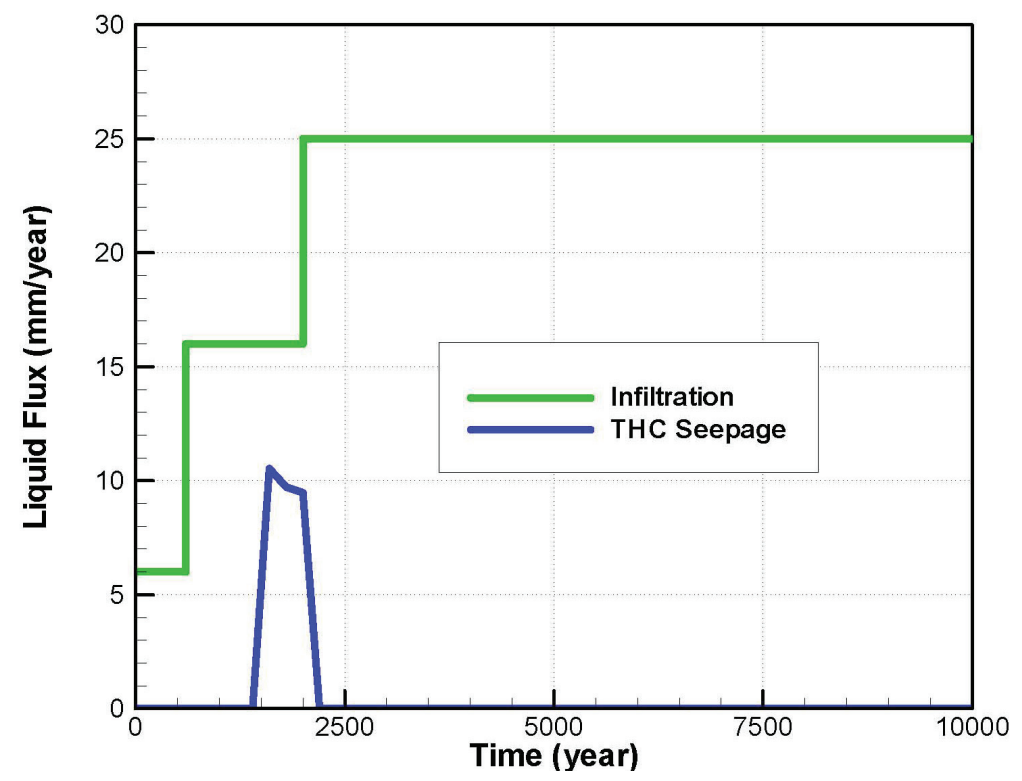

Figure 11. Rate of seepage into emplacement tunnels as a function of time for THC simulations with infiltration fluxes PMF1 and Realization 1 of the fracture permeability distribution. No seepage was observed in ambient or TH simulations.
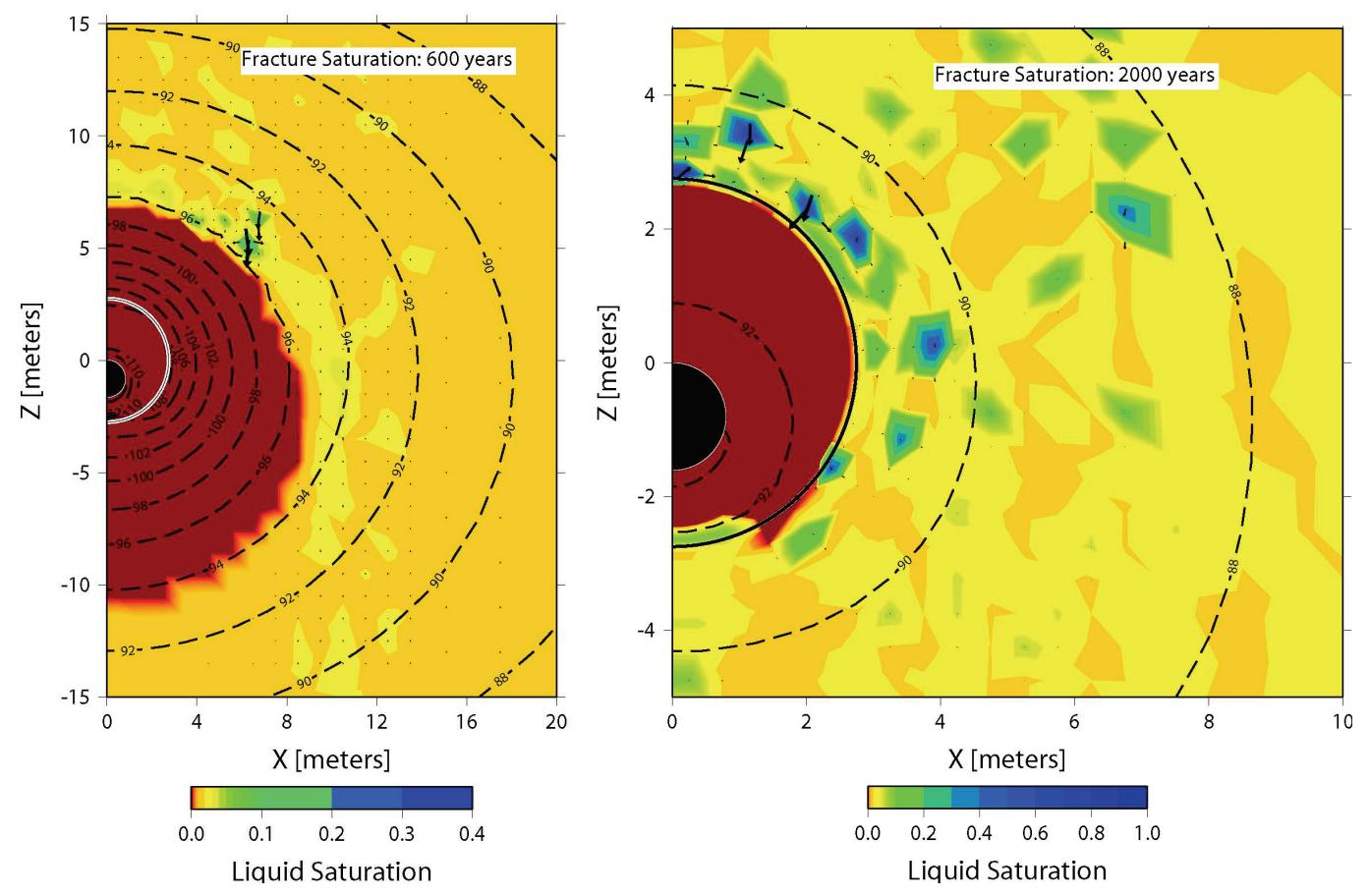

Figure 12. Contours of temperature and liquid saturation, and liquid flux vectors in the vicinity of the emplacement tunnels in THC simulations with infiltration fluxes of PMF1 and including Leverett scaling effects: (a) 600 years (left) and (b) 2,000 years (right). Note the difference in saturation scales. 


\section{Sensitivity Analyses}

\subsection{Sensitivity to Infiltration Fluxes}

Figure 13 shows the transient seepage fluxes from ambient, $\mathrm{TH}$, and THC simulations, when the applied fluxes are ten times $(60,160$, and $250 \mathrm{~mm} /$ year during 0-600, 600-2,000, and beyond 2,000 years, respectively) larger than the PMF1 infiltration fluxes (see Section 2.4). Figure 13a is obtained without consideration of dynamic capillarity changes, i.e., without Leverett scaling. In Figure 13a, ambient seepage is predicted to commence after 600 years (with the enhancement of infiltration fluxes from 60 $\mathrm{mm} /$ year to $160 \mathrm{~mm} /$ year). On the other hand, detectable TH seepage is not expected until about 1,400 years. The THC simulations, however, predict that seepage can commence around 1,000 years. From Figure 13a, it is also observed that TH seepage is always smaller than ambient seepage. However, THC seepage may exceed ambient seepage at very large times. Seepage in these simulations (ambient, TH, or THC) occurs because the infiltration fluxes are large enough to cause saturation buildup in excess of the saturation threshold in some gridblocks just above the tunnel (see Equation 5). Even though capillarity changes are ignored in these simulations, the porosity and permeability changes result in a different seepage saturation threshold (Equation 10) in the THC simulations compared to the TH simulations, explaining the difference in the transient seepage pattern between the two scenarios.

As mentioned earlier, ignoring the impact of dynamic capillarity changes may result in an overprediction of seepage. This is more clearly seen when Figure 13a is compared with Figure $13 \mathrm{~b}$. First, when capillary changes are included (Figure 13b), THC seepage is always smaller than ambient seepage. Thus, it is possible that the larger-than-ambient seepage at very large times in THC simulations of Figure 13a results from not including the Leverett-scaling effects and is simply an overprediction. It is also noted from both Figures 13a and 13b, that THC seepage is expected to be larger than $\mathrm{TH}$ seepage. Thus, feedback of THC processes is important while predicting seepage in emplacement tunnel. It also shows that dynamic capillarity changes play an important role in determining the duration and amount of seepage. 


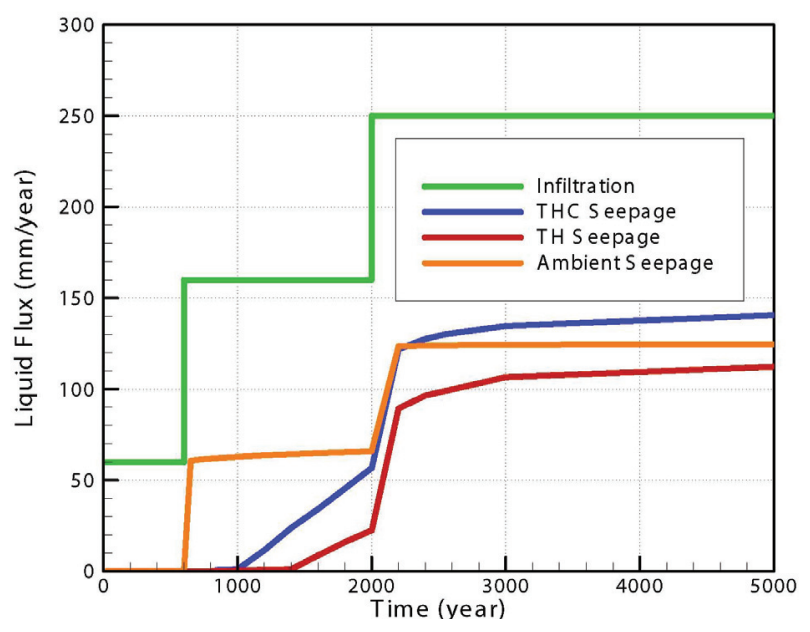

Figure 13a. Rate of seepage into emplacement tunnels as a function of time for ambient, TH, and THC simulations with infiltration fluxes ten times that of PMF1 and Realization 1 of the fracture permeability distribution. Leverett-scaling effects have not been included in these simulations

\subsection{Sensitivity to Heterogeneity in Fracture Permeability Field}

The results shown thus far were obtained with one realization of the fracture permeability field (Figure 5). Three different realizations of the same fracture permeability field (see Section 3.5) were generated. Ambient, TH, and THC simulations with PMF1 infiltration fluxes were carried out with each of these initial permeability distributions. Simulations were performed for all these scenarios with and without Leverett scaling effects.

When the infiltration fluxes are PMF1, seepage does not occur for the ambient or TH simulations with any of the three permeability realizations when Leverett-scaling is ignored. The transient pattern of THC seepage for Realization 2 is similar to that of Realization 1 (see Figure 
11), though the maximum predicted seepage rate is marginally higher for Realization 2 . On the other hand, for the third realization of the permeability field, seepage is almost negligible (less than $1 \mathrm{~mm} / \mathrm{yr}$ ). When Leverett scaling effects are included, no seepage occurred from either the ambient, TH, or THC simulations for two of the three realizations. However, results from a third realization show seepage for all of ambient, TH, and THC conditions. It was also seen that the ambient seepage was larger than THC seepage. Simulations with more realizations of the fracture permeability distribution may be necessary to obtain an average likelihood of seepage or an average rate of seepage. In summary, the observations from this study illustrate the importance of THC processes in controlling seepage.

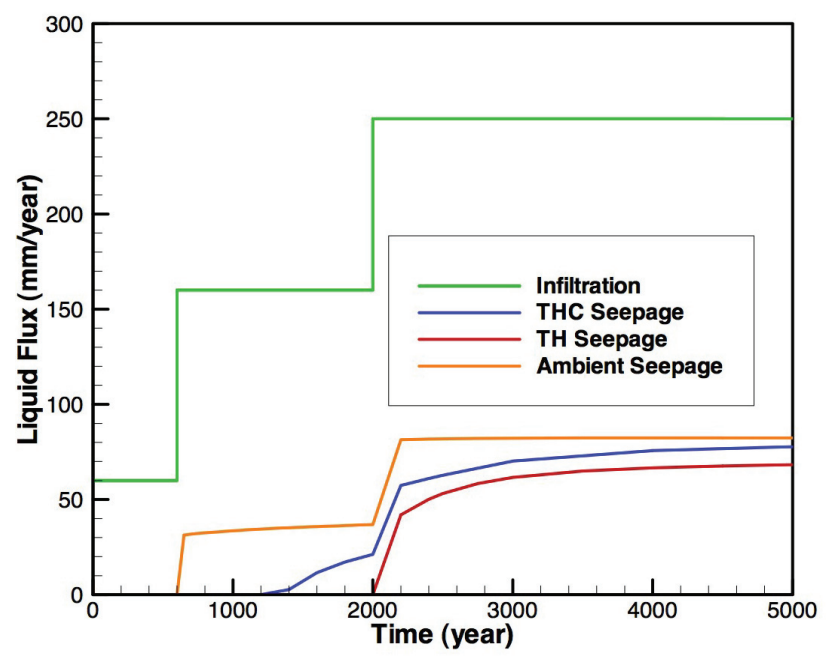

Figure 13b. Rate of seepage into emplacement tunnels as a function of time for ambient, TH and THC simulations with infiltration fluxes ten times that of PMF1 and Realization 1 of the fracture permeability distribution. Leverett-scaling effects have been included in these simulations 


\section{Conclusions}

The feedback of geochemical processes resulting from heat released by radioactive wastes emplaced in subsurface tunnels on the hydrologic properties of the unsaturated host rock is investigated in this paper. It is shown that the THC processes of mineral precipitation and dissolution can alter the porosity, permeability, and other hydrologic properties of the unsaturated rock in the vicinity of an emplacement tunnel. Under certain circumstances, when these THC-induced hydrologic property alterations are imposed on the natural heterogeneity of the rock, the flow field around a tunnel is subjected to significant perturbation, often leading to channeling of flow onto certain preferred locations (depending upon permeability and porosity distributions at a given time) above the tunnel. Such local flow channeling in THC simulations may sometimes lead to larger seepage compared to TH-only models, i.e., when feedback of the THC processes on hydrologic properties are ignored. It has been also shown that the predicted flow channeling (and subsequent seepage) is more when the impact of THC processes on capillary properties of the rock is ignored. When the impact of THC processes on capillarity is also included, larger seepage is still obtained in THC simulations than in TH simulations. However, the THC seepage in this latter scenario is less than ambient seepage.

We have demonstrated how the occurrence of seepage can be explained in terms of dynamic porosity, permeability, and capillarity changes resulting from mineral precipitation and dissolution. However, seepage occurrence and its rate is sensitive to various other factors, such as the imposed infiltration fluxes, the fracture capillary strength of the host rock, the underlying heterogeneity in fracture permeability, and the permeability-porosity relationship implemented in the model, which all have inherent uncertainties. The impact of time and space discretization on the results is also currently under investigation. Therefore, the results presented in this paper should be regarded as an illustration of the possibility of enhanced seepage (compared to TH only models) caused by mineral precipitation. It should also be noted that ignoring feedback of THC processes on capillarity, while including those on porosity and permeability, might result in prediction of seepage that is higher than ambient seepage. On the other hand, although our modeling results show that seepage predicted with THC simulations can be larger than the seepage predicted when mineral precipitation/dissolution is ignored (i.e., TH only simulations), the larger seepage generally remains below seepage fluxes predicted under ambient conditions, provided that feedback of THC processes on not only porosity and permeability, but also on capillarity, are included in the predictive model. 


\section{Acknowledgment}

This work was supported by the Director, Office of Civilian Radioactive Waste Management, U.S. Department of Energy, through Memorandum Purchase Order EA9013MC5X between Bechtel SAIC Company, LLC, and the Ernest Orlando Lawrence Berkeley National Laboratory (Berkeley Lab). The support is provided to Berkeley Lab through the U.S. Department of Energy Contract No. DE-AC0205CH11231. Review and comments of Guoxiang Zhang and Dan Hawkes from Berkeley Lab are greatly appreciated. Assistance of Diana Swantek form Berkeley Lab in preparing Figures 1 and 2 is thankfully acknowledged. Figures 6, 7, 8 and 12 were developed using the software Generic Mapping Tool (Wessel and Smith, 1998).

\section{Nomenclature}

$A_{i j} \quad$ Interface area between gridblocks 'i' and 'j' $\left[\mathrm{m}^{2}\right]$

$\mathrm{A}_{\mathrm{s}} \quad$ Interface area between any gridblock and the emplacement tunnel $\left[\mathrm{m}^{2}\right]$

$b_{g} \quad$ Fracture geometric aperture [m]

$b_{0, h} \quad$ Initial fracture hydraulic aperture [m]

$\Delta b \quad$ Change in fracture hydraulic aperture [m]

$F(-) \quad$ Functional dependence of capillary pressure on liquid saturation [-]

$g \quad$ Acceleration due to gravity $\left[\mathrm{ms}^{-2}\right]$

$h \quad$ Distance [m]

$k_{0} \quad$ Mean fracture permeability [ $\left.\mathrm{m}^{2}\right]$

$k_{i} \quad$ Permeability of gridblock ' $i$ ' $\left[\mathrm{m}^{2}\right]$

$k_{f} \quad$ Fracture permeability $\left[\mathrm{m}^{2}\right]$

$k_{0, f} \quad$ Initial fracture permeability $\left[\mathrm{m}^{2}\right]$

$k_{m} \quad$ Matrix permeability $\left[\mathrm{m}^{2}\right]$

$k_{0, m} \quad$ Initial matrix permeability $\left[\mathrm{m}^{2}\right]$

$k_{s} \quad$ Vertical permeability between the last rock gridblock and the tunnel $\left[\mathrm{m}^{2}\right]$

$m \quad$ van Genuchten exponent [-]

$P_{C} \quad$ Capillary pressure $[\mathrm{Pa}]$

$q_{i j} \quad$ Liquid flow rate from gridblock ' $j$ ' to gridblock ' $i$ ' $\left[\mathrm{m} \mathrm{s}^{-1}\right]$

$q_{s} \quad$ Rate of Seepage $\left[\mathrm{ms}^{-1}\right]$

$S_{i}^{l} \quad$ Liquid saturation of gridblock ' $i$ ' [-]

$S_{i}^{l r} \quad$ Residual liquid saturation of gridblock ' $i$ ' [-]

$S_{i}^{l, e} \quad$ Effective saturation of gridblock ' $i$ ' [-]

$S_{i}^{l t} \quad$ Seepage threshold saturation [-]

$s \quad$ Fracture spacing [m]

$t \quad$ Time [s] 
$V_{i} \quad$ Volume of gridblock ' $i$ ' $\left[\mathrm{m}^{3}\right]$

Greek Symbols

1/a Fracture capillary strength parameter [Pa]

$1 / \alpha_{0} \quad$ Mean fracture capillary strength parameter [Pa]

$1 / \alpha_{i} \quad$ Fracture capillary strength parameter of gridblock ' $i$ ' $[\mathrm{Pa}]$

$\gamma \quad$ Active fracture parameter [-]

$\mu \quad$ Viscosity of water $\left[\mathrm{kg} \mathrm{m}^{-1} \mathrm{~s}^{-1}\right]$

$\rho \quad$ Density of water $\left[\mathrm{kg} \mathrm{m}^{-3}\right]$

$\varphi_{0} \quad$ Mean fracture porosity [-]

$\varphi_{i} \quad$ Fracture porosity of gridblock ' $i$ ' [-]

$\phi_{f} \quad$ Fracture porosity [-]

$\phi_{0, f} \quad$ Initial fracture porosity [-]

$\phi_{m} \quad$ Matrix porosity [-]

$\phi_{0, m} \quad$ Initial matrix porosity [-]

\section{References}

Birkholzer, J.T., (2004) Abstraction of Drift Seepage, MDL-NBS-HS-000019 REV 01, Bechtel SAIC Company, Las Vegas, NV, 2004.

Birkholzer, J.T., and Tsang, Y.W., Modeling the Thermal-Hydrologic Processes in a Large-Scale Underground Heater Test in Partially Saturated Fractured Tuff, Water Resources Research, vol. 36(6), pp. 1431-1447, 2000.

Birkholzer, J.T., Mukhopadhyay, S., and Tsang, Y.W., Modeling Seepage Into Heated Waste Emplacement Tunnels in Unsaturated Fractured Rock, Vadose Zone Journal, vol. 3, pp. 819-836, 2004.

Birkholzer, J.T., Mukhopadhyay, S., and Tsang, Y.W., Drift-Scale Coupled Processes (DST and TH Seepage) Models, MDL-NBS-HS-000015 REV 02, Bechtel SAIC Company, Las Vegas, NV, 2005.

Buscheck, T.A., and Nitao, J.J., Repository-Heat-Driven Hydrothermal Flow at Yucca Mountain, Part I: Modeling and Analysis, Nuclear Technology, vol. 104(3), pp. 418-448, 1993.

Buscheck, T.A., Rosenberg, N.D., Gansemer, J., and Sun Y., Thermohydrologic Behavior at an Underground Nuclear Waste Repository, Water Resources Research, vol. 38(3), pp. 1-19, 2002.

Campbell, C.G., Levitt, D., and Bakr, A., Future Climate Analysis, ANL-NBS-GS-000008 REV 01, Bechtel SAIC Company, Las Vegas, NV, 2004.

Carman, P.C., Fluid Flow Through a Granular Bed, Transactions of the Institution of Chemical Engineers, vol. 15, pp. 150-167, 1937. 
Finsterle, S., Using the Continuum Approach to Model Unsaturated Flow in Fractured Rock, Water Resources Research, vol. 36, pp. 2055-2066, 2000.

Finsterle, S., Ahlers, C.F., Trautz, R.C., and Cook P.J., Inverse and Predictive Modeling of Seepage Into Underground Openings, Journal of Contaminant Hydrology, vol. 62-63, pp. 89-109, 2003.

Finsterle, S., Trautz, R.C., Cook, P.J., Ghezzehei, T.A., and Ahlers, C.F., Seepage Calibration Model and Seepage Testing Data, MDL-NBS-HS-000004 REV 03, Bechtel SAIC Company, Las Vegas, NV, 2004.

Ghezzehei, T.A., and Liu, H.H., Calibrated Properties Model, MDL-NBS-HS-000003 REV 02, Bechtel SAIC Company, Las Vegas, NV, 2004.

Ghezzehei T.A., Trautz, R.C., Finsterle, S., Cook, P.J., and Ahlers, C.F., Modeling Coupled Evaporation and Seepage in Ventilated Cavities, Vadose Zone Journal, vol. 3, pp. 806-818, 2004.

Haukwa, C.B., Wu, Y-S, and Bodvarsson, G.S., Thermal Loading Studies Using the Yucca Mountain Unsaturated Zone Model, Journal of Contaminant Hydrology, vol. 38(1-3), pp. 217-255, 1999.

Haukwa, C.B., Tsang, Y.W., Wu, Y-S, and Bodvarsson, G.S., Effect of Heterogeneity on the Potential for Liquid Seepage Into Heated Emplacement Drifts of the Potential Repository, Journal of Contaminant Hydrology, vol. 62-63, pp. 509-527, 2003.

Houseworth, J., Future Climate Analysis, ANL-NBS-GS-000008 REV 00 ICN 01, U.S. Geological Survey, Denver, CO, 2001.

Jackson, C.P., Hoch, A.R., and Todman, S., Self-Consistency of a Heterogeneous Continuum Porous Medium Representation of a Fractured Medium, Water Resources Research, vol. 36, pp. 189-202, 2000.

Johnson, J.W., Oelkers, E.H., and Helgeson, H.C., SUPCRT92: A Software Package for Calculating the Standard Molal Thermodynamic Properties of Minerals, Gases, Aqueous Species, and Reactions From 1 to 5000 bars and 0 to 1000 degrees C, Computers and Geosciences, vol. 18, pp. 899-948, 1992.

Kneafsey, T.J., and Pruess, K., Laboratory Experiments on Heat-Driven Two-Phase Flows in Natural and Artificial Rock Fractures, Water Resources Research. vol. 34(12), pp. 3349-3367, 1998.

Lasaga, A.C., Kinetic Theory in the Earth Sciences, Princeton University Press, Princeton, 1998.

Leverett, M.C., Capillary Behavior in Porous Solids, Petroleum Development Technology, vol. 142, pp. 152-169, 1941.

Li, G., and Tsang, C.F., Seepage Into Drifts With Mechanical Degradation, Journal of Contaminant Hydrology, vol. 62-63, pp. 157-172, 2003.

Liu, H.H., Doughty, C., and Bodvarsson, G.S., An Active Fracture Model for Unsaturated Flow and Transport in Fracture Rocks, Water Resources Research, vol. 34(10), pp. 2633-2646, 1998. 
Mukhophadhyay, S., and Tsang, Y.W., Understanding the Anomalous Temperature Data From the Large Block Test at Yucca Mountain, Nevada, Water Resources Research, vol. 38(10), pp. 28-1 through 28-12, 2002.

Mukhophadhyay, S., and Tsang, Y.W., Uncertainties in Coupled Thermal-Hydrological Processes Associated With the Drift Scale Test at Yucca Mountain, Nevada, Journal of Contaminant Hydrology, vol. 62-63, pp. 595-612, 2003.

Mukhopadhyay, S., Sonnenthal, E.L., and Spycher, N., Modeling Coupled Thermal-HydrologicalChemical Processeses in the Unsaturated Fractured Rock of Yucca Mountain, Nevada: Heterogeneity and Seepage, Physics and Chemistry of the Earth, vol. 31, pp. 626-633, 2006.

Or, D., and Ghezzehei, T.A., Dripping Into Subterranean Cavities From Unsaturated Fractures Under Evaporative Conditions, Water Resources Research, vol. 36, pp. 381-393, 2000.

Panda, M.N., and Lake, L.W., Estimation of Single-Phase Permeability From the Parameters of a Particle-Size Distribution, AAPG Bulletin, vol. 78, pp. 1028-1039, 1994.

Philip, J.R., Knight, J.H., and Waechter, R.T., Unsaturated Seepage and Subterranean Holes: Conspectus, and Exclusion Problem for Circular Cylindrical Cavities, Water Resources Research, vol. 25(1), pp. 16-28, 1989.

Pruess, K., TOUGH2 - A General Purpose Numerical Simulator for Multiphase Fluid and Heat flow, LBNL-29400, Lawrence Berkeley National Laboratory, Berkeley, CA, 1991.

Pruess, K., On Vaporizing Water Flow in Hot Sub-Vertical Rock Fractures, Transport in Porous Media, vol. 28(3), pp. 335-372, 1997.

Pruess, K., Tsang, Y.W., and Wang, J.S.Y., Numerical Studies of Fluid and Heat Flow Near High-Level Nuclear Waste Packages Emplaced in Partially Saturated Fractured Tuff, LBNL-18552, Lawrence Berkeley National Laboratory, Berkeley, CA, 1984.

Pruess, K., Wang, J.S.Y., and Tsang, Y.W., On Thermohydrologic Conditions Near High- Level Nuclear Wastes Emplaced in Partially Saturated Fractured Tuff, 1. Simulation Studies With Explicit Consideration of Fracture Effects, Water Resources Research, vol. 26(6), pp. 1235-1248, 1990.

Pruess, K., Oldenburg, C.M., and Moridis, G.J., TOUGH2 User's Guide, Version 2.0, LBNL-43134, Lawrence Berkeley National Laboratory, Berkeley, CA, 1999.

Sonnenthal, E.L., Spycher, N., Apps, J., and Conrad, M.A., Conceptual Model for Reaction-Transport Processes in Unsaturated Fractured Rocks at Yucca Mountain: Model Validation Using the Drift Scale Heater Test, Eleventh Annual V.M. Goldschmidt Conference, Hot Springs, Virginia, 2001.

Sonnenthal, E.L., Spycher, N., and Xu, T., Linking Reaction, Transport, and Hydrological Parameters in Unsaturated Fractured rock: TOUGHREACT Implementation and Application, TOUGH Symposium 2003 Proceedings, LBNL-52494, Lawrence Berkeley National Laboratory, Berkeley, CA, 2003.

Sonnenthal, E.L., and Spycher, N., Progress Towards Understanding Thermal, Hydrological and Chemical Processes in Unsaturated Fractured Rocks at Yucca Mountain, In: Faybishenko B, 
Witherspoon P (eds) Proceedings of the $2^{\text {nd }}$ International Symposium on Dynamics of Fluids in Fractured Rock, Lawrence Berkeley National Laboratory, Berkeley, CA, 2004.

Sonnenthal, E.L., Ito, A., Spycher, N., Yui, M., Apps, J., Sugita, Y., Conrad, M., and Kawakami S., Approaches to Modeling Coupled Thermal, Hydrological, and Chemical Processes in the Drift Scale Heater Test at Yucca Mountain, International Journal of Rock Mechanics and Mining Sciences, vol. 42, pp. 698-719, 2005.

Spycher, N., Sonnenthal, E.L., and Apps J., Prediction of Fluid Flow and Reactive Transport Around Potential Nuclear Waste Emplacement Tunnels at Yucca Mountain, Nevada, Journal of Contaminant Hydrology, vol. 62-63, pp. 653-673, 2003.

Spycher, N., Sonnenthal, E.L., Kneafsey, T.J., and Dobson, P., An integrated Approach to Predict Coupled Processes at a Nuclear Waste Repository, Wanty RB, Seal RR (eds) Water-Rock Interaction, WRI-11, Balkema Publishers, New York, NY, 2004.

Spycher, N., Sonnenthal, E.L., and Bryan, C., Drift-scale Coupled Processes (DST and THC Seepage) Models, MDL-NBS-HS-000001 REV04, Bechtel SAIC Company, Las Vegas, NV, 2005a.

Spycher, N., Mukhopadhyay, S., Shields, D., Leem, J., Bryan, C., and Sonnenthal, E.L., (2005) THC Sensitivity Study of Repository Edge and Heterogeneous Permeability Effects, ANL-NBS-HS-000047 REV 00, Bechtel SAIC Company, Las Vegas, NV, 2005b.

Trautz, R.C., and Wang, J.S.Y., Seepage Into an Underground Opening Constructed in Unsaturated Fractured Rock Under Evaporative Conditions, Water Resources Research, vol. 38(10), pp. 6-1 through 6-14, 2002.

Tsang, C.F., Li, G., Rutqvist, J., and Zhou, Q., Seepage Model for PA Including Drift Collapse. MDLNBS-HS-000002 REV 03, Bechtel SAIC Company, Las Vegas, NV, 2004.

Tsang, Y.W., and Birkholzer, J.T., Predictions and Observations of the Thermal-Hydrologic Conditions in the Single Heater Test, Journal of Contaminant Hydrology, vol. 38(1-3), pp. 395-426, 1999.

van Genuchten, M.T., A Closed-Form Equation for Predicting the Hydraulic Conductivity of Unsaturated Soils, Soil Science Society of America Journal, vol. 44, pp. 892-898, 1980.

Wang, J.S.Y., Trautz, R.C., Cook, P.J., Finsterle, S., James, A.L., and Birkholzer, J.T., Field Tests and Model Analyses of Seepage Into Drift, Journal of Contaminant Hydrology, vol. 38(1-3), 323-347, 1999.

Wessel, P., and Smith, W.H.F., New, Improved Version of Generic Mapping Tools Released, EOS Trans, Amer. Geophys. U, vol. 79, pp. 579, 1998.

Wu, Y-S., Mukhopadhyay, S., Zhang, K., and Bodvarsson, G.S., A Mountain-Scale Thermal-Hydrologic Model for Simulating Fluid Flow and Heat Transfer in Unsaturated Fractured Rock, Journal of Contaminant Hydrology, vol. 86, pp. 128-159, 2006.

$\mathrm{Xu}, \mathrm{T}$., and Pruess, K., Modeling Multiphase Fluid Flow and Reactive Geochemical Transport in Variably Saturated Fractured Rocks: 1. Methodology, Am. J. Sci., vol. 301, pp. 16-33, 2001. 
Xu, T., Sonnenthal, E.L., Spycher, N., and Pruess, K., TOUGHREACT User's Guide: A Simulation Program for Non-Isothermal Multiphase Reactive Geochemical Transport in Variable Saturated Geologic Media, LBNL-55460, Lawrence Berkeley National Laboratory, Berkeley, CA, 2004.

Xu, T., Sonnenthal, E.L., Spycher, N., and Pruess, K., TOUGHREACT - A Simulation Program for Non-Isothermal Multiphase Reactive Geochemical Transport in Variably Saturated Geologic Media: Applications for Geothermal Injectivity and $\mathrm{CO}_{2}$ Geologic Sequestration, Computers and Geosciences, vol. 32, pp. 145-165, 2006. 